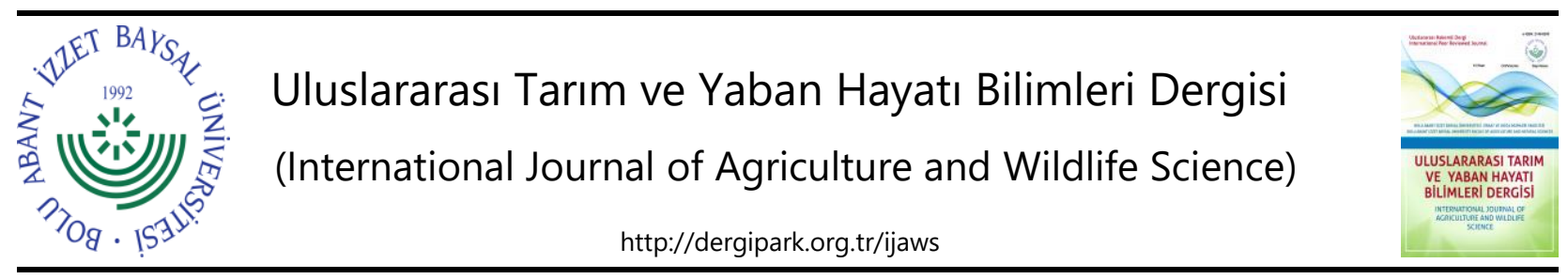

Araştırma Makalesi

\title{
Çukurova Ekolojik Koşullarına Uygun Bazı Karpuz Çeşitlerinin Kuraklığa Tolerans Seviyelerinin Belirlenmesi ${ }^{* \star}$
}

\author{
Hayriye Yıldız Daşgan $^{1 *}$ (D) $\quad$ Musa Kılınç ${ }^{1}$ (D) $\quad$ Sultan Dere ${ }^{2}$ (D) $\quad$ Boran Íkiz $^{1 \text { (D) }}$ \\ ${ }^{1}$ Çukurova Üniversitesi, Ziraat Fakültesi, Bahçe Bitkileri Bölümü, Adana \\ ${ }^{2}$ Siirt Üniversitesi, Ziraat Fakültesi, Bahçe Bitkileri Bölümü, Siirt
}

Geliş tarihi (Received): 03.08.2021 Kabul tarihi (Accepted): 09.11.2021

\begin{abstract}
Anahtar kelimeler:
Citrullus lanatus, kuraklık, fizyolojik parametreler, verim, kalite.

Özet. Bu çalışmada, ülkemizde karpuz üretiminde çok önemli bir bölge olan Çukurova ekolojik koşullarına uygunluğu daha önceki adaptasyon denemeleriyle ortaya konan yeni karpuz çeşit adaylarının kuraklık stresine karşı tepkilerinin ortaya çıkarılması amaçlanmıştır. Çalışma, Çukurova Üniversitesi Ziraat Fakültesi Bahçe Bitkileri Bölümü'ne ait açık arazi deneme alanında ve Bitki Fizyolojisi Laboratuvarında yürütülmüştür. Bitki materyali olarak Minipool, 50024, Miracle, Splendit çeşit adayları ve Starburst karpuz çeşidi kullanılmıştır. Çalışmada üç farklı seviyede sulama yapılmıştı; 1) kontrol olarak tam sulanan parseller, 2) kontrolün yarısı kadar (\%50 sulama) ve 3) kontrolün 1/4'ü kadar (\%25) sulanan parsellerdir. Çalışma sonunda çeşit adaylarının kuraklık stresi altında bitki büyümesi, verim ve meyve kalitesinde ortaya çıkan değişiklikler agronomik, fizyolojik ve pomolojik olarak incelenmiştir. Karpuz üretiminde Çukurova bölgesi ekolojik koşullarında \%75 su kısıtlamasına kadar olan stres koşullarında başarılı bulunan çeşitler Splendit ve Miracle olmuştur. Özel durumlarda suyun \%50 kısıtı aşmaması halinde Starburst ve 50024 numaralı çeşitler de tercih edilebilir bulunmuştur

*Sorumlu yazar dasgan@cu.edu.tr
\end{abstract}

\section{Determination of Drought Tolerance Levels of Watermelons Suitable to Cukurova Region Ecological Conditions}

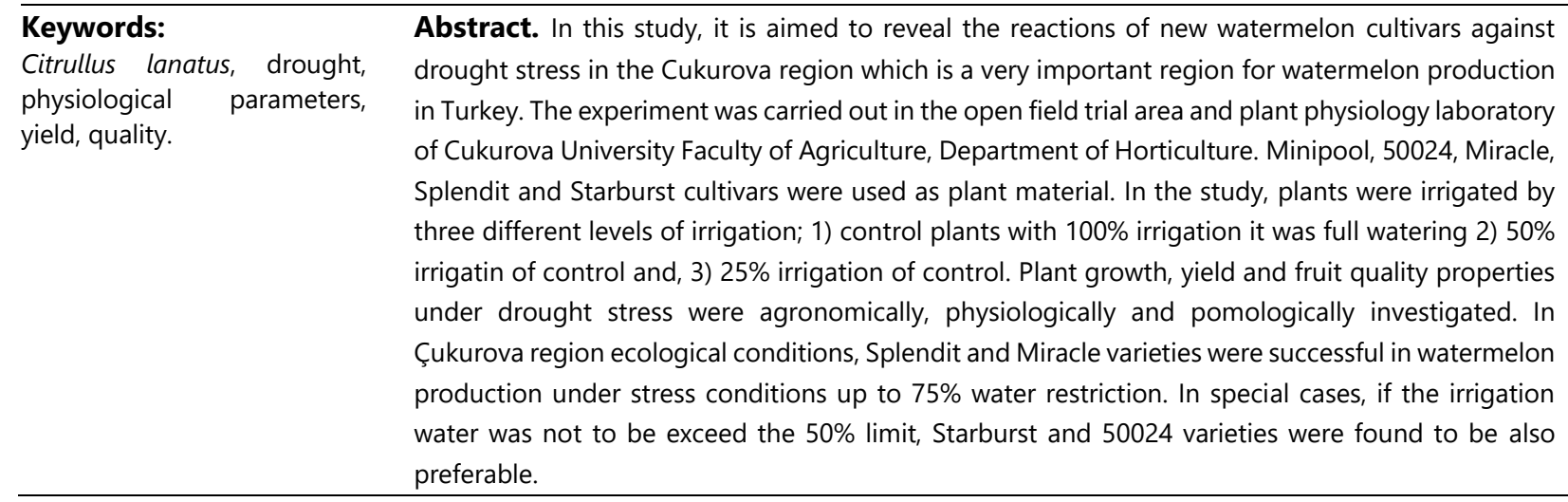




\section{GiRiş}

Kuraklık, genel anlamda meteorolojik bir olgu olup toprağın su içeriği ile bitki gelişiminde gözle görülür azalmaya neden olacak kadar uzun süren yağışsız dönemdir. Yağışsız dönemin kuraklık oluşturması; toprağın su tutma kapasitesi ve bitkilerin evapo-transpirasyon hızına bağlı olarak gerçekleşmektedir (Jones ve Corlett, 1992; Kozlowski ve Pallardy, 1997).

Ülkemizin çeşitli bölgelerinin küresel ısınma ve iklim değişikliği etkileri altında; iklim değişikliğinden farklı biçimde ve değişik boyutlarda etkileneceği öngörülmektedir Çölleşme tehdidi altında bulunan Güney Doğu ve iç Anadolu'nun kurak ve yarı kurak bölgeleriyle, yeterli suya sahip olmayan yarı nemli Ege ve Akdeniz bölgelerinin daha fazla etkileneceği öngörülmektedir.

Türkiye'nin pek çok bölgesinde hâkim olan su kıtlığı, tarım ve enerji üretimi için önemli olduğu kadar, içme suyu, hidrolojik sistemler ve su kaynakları yönetimi açısından da oldukça büyük önem taşımaktadır (Kapluhan, 2013).

Besleyici özellikleri ve insan sağlığına olan koruyucu özellikleri açısından önemli bir rol oynamakta olan sebzeler, insan metabolizmasının gerek duyduğu vitamin ve mineral ihtiyacını karşılamaktadır. Yaz mevsiminde insanların su ihtiyacını gidermesi ve içerdiği vitaminler, mineraller ve likopen yönünden zenginliği yönüyle karpuz önemli bir sebzedir. Dünyada en çok üretilen ve tüketilen sebze türlerinden biri olan karpuz (Citrullus lanatus), tek yıllık bir kültür bitkisidir. FAO'nun 2018 yılı raporlarına göre dünyada ortalama 3.241.239 ha alanda 103.931.337 ton karpuz üretilmektedir (Anonim, 2021a). Dünya karpuz üretiminde ülkemiz 95.328 ha alanda 4.031 .174 milyon ton üretim değeri ile Çin ve İran'dan sonra 3. sıradadır. Türkiye'de 2020 yılı verilerine göre 3.491,554 ton karpuz üretimi gerçekleşmiş ve bu üretimin yaklaşık 70 bin tonu ihraç edilmiştir (Anonim, 2021b).

Küresel ısınmanın etkilerini fazlasıyla gördüğümüz günümüzde, kuraklık ve abiyotik streslere dayanıklı bitki tür ve çeşitlerinin, ilerleyen zamanlarda insanların gıda ve diğer yaşamsal ihtiyaçlarını karşılamada önemli olacağı öngörülmektedir. Bu türlerden biri olan karpuz bitkisi de, sulu koşullarda yüksek verim elde edilen bir tür olmasının yanı sıra, kurak koşullarda da uyum sağlayabilen ve bünyesindeki su ile kendini tolere edebilen bir bitki türüdür (Yokota ve ark., 2002).

Dünya nüfusunun \%40'ından fazlasının 2050 yılında su stresi görülen havzalarda yaşaması beklenen bir durumdur (Öktem ve Aksoy, 2014). İklim değişikliğinin tarımsal üretimi etkilemeye başladığı günümüzde, kuraklık stresine toleranslı çeşitlerin ortaya çıkarılarak üreticilere önerilmesinin önemli olduğu düşünülmektedir. Bu çalışmada, Çukurova ekolojik koşulları için adaptasyon çalışmaları özel bir tohum firması tarafından yapılan ve yöre halkının tüketim alışkanlıklarına uygun yeni geliştirilen güncel dört karpuz çeşidinin kuraklık stresine tepkileri, tolerans düzeyleri agronomik, fizyolojik ve pomolojik olarak incelenmiştir.

\section{MATERYAL VE METOT}

Çalışma, Çukurova Üniversitesi Ziraat Fakültesi Bahçe Bitkileri Bölümü'ne ait açık arazi deneme alanında, ölçüm ve değerlendirmeleri ise Bitki Fizyoloji Laboratuvarı'nda gerçekleştirilmiştir.

Bitkisel materyal olarak, Hazera tohum firmasının Çukurova ekolojik koşulları için adaptasyon çalışmalarını yaptığı ve yöre halkının tüketim alışkanlıklarına uygun dört adet yeni $F_{1}$ hibrit çeşit adayı ve bir adet kontrol çeşidi kullanılmıştır. Kontrol çeşidi olarak, Çukurova'da üreticiler tarafından tercih edilen çeşitlerden birisi olan Seminis firmasının Starburst $F_{1}$ çeşidi seçilmiştir. Çalışmada kullanılan karpuz çeşit adaylarının kodlamaları Çizelge 1'de verilmiştir.

Çizelge 1. Denemede kullanılan karpuz kod numarası ve isim bilgileri.

Table 1. Watermelon code number and commercial cultivar name information used in the experiment.

\begin{tabular}{lll}
\hline Sira no & Kod no & Ticari adı \\
\hline 1 & HWX1001 & 52024 \\
2 & HWX1002 & Minipool \\
3 & HWX1003 & Miracle \\
4 & HWX1004 & Splendit \\
5 & HWX1005 & Starburst \\
\hline
\end{tabular}

Deneme alanından dikimden önce toprak örneği alınarak bitki besin maddeleri ve tekstür bakımından analiz edilmiş olup, analiz sonuçları bitki besleme ve sulama konularında ışık tutmuştur (Çizelge 2). Çalışma açıkta karpuz yetiştiriciliği şeklinde gerçekleştirilmiştir. 
Çizelge 2. Deneme alanından alınan toprak örneği analiz sonuçları.

Table 2. Soil sample analysis results from the experimental area.

\begin{tabular}{llll}
\hline Analiz Adı & Birimi & Metod & Sonuç \\
\hline $\mathrm{pH}$ & - & Saturasyon çamuru & 7.70 \\
$\mathrm{EC}$ & $\mathrm{ds} \mathrm{m}^{-1}$ & Saturasyon çamuru & 0.21 \\
$\mathrm{CaCO}_{3}$ (Kireç) & $\%$ & Kalsimetre & 20.33 \\
Organik Madde & $\%$ & W.Black & 1.23 \\
Fosfor $\left(\mathrm{P}_{2} \mathrm{O}_{5}\right)$ & $\mathrm{kg} \mathrm{da}-1$ & Askorbik asit & 13.83 \\
Potasyum $\left(\mathrm{K}_{2} \mathrm{O}\right)$ & $\mathrm{kg} \mathrm{da}^{-1}$ & A.Asetat-ICP & 72.52 \\
Kalsiyum $(\mathrm{Ca})$ & $\mathrm{mg} \mathrm{kg}^{-1}$ & A.Asetat-ICP & 8132 \\
Tuz & $\%$ & Saturasyon çamuru & 0.01 \\
Bünye & $\%$ & Saturasyon çamuru & Killi Tınlı \\
Çinko $(\mathrm{Zn})$ & $\mathrm{mg} \mathrm{kg}{ }^{-1}$ & DTPA (ICP) & 0.603 \\
Demir $($ Fe) & DTPA (ICP) & 5.121 \\
Mangan (Mn) & $\mathrm{mg} \mathrm{kg}^{-1}$ & DTPA (ICP) & 2.124 \\
Bakır $(\mathrm{Cu})$ & $\mathrm{mg} \mathrm{kg}^{-1}$ & DTPA (ICP) & 0.254 \\
Su ile Doygunluk & $\mathrm{mg} \mathrm{kg}^{-1}$ & & 59.40 \\
\hline
\end{tabular}

Deneme üç uygulama şeklinde kurulmuştur. Bunlardan birisi kontrol olarak düşünülen ve tam sulanan parseller, ikincisi kontrolün yarısı kadar \%50 sulanan (\%50 su stresi) parseller ve üçüncüsü ise kontrolün $1 / 4^{\prime}$ ü kadar \%25 sulanan (\%75 su stresi) parsellerden oluşmuştur. Deneme bölünmüş parseller deneme deseninde 4 tekerrürlü ve her tekerrürde 10 bitki olacak şekilde düzenlenmiştir. Fideler, hazır fide üreten bir fide firmasında üretilmiş ve araziye 13 Nisan 2019 tarihinde dikilmiştir. Karpuz fidelerinde dikim mesafeleri sıra arası $200 \mathrm{~cm}$ ve sıra üzeri 50 $\mathrm{cm}$ olarak düzenlenmiştir. Araziye dikilen karpuz fideleri tüm uygulamalarda 30 gün boyunca optimum düzeyde sulanmışır. Daha sonraki sulamalar deneme planı dâhilinde tam sulama (kontrol), kontrolün yarısı ve $1 / 4^{\prime}$ ü kadar kısıtlı sulama şeklinde devam etmiştir. Günlük olarak buharlaşma kazanından (Class Apan) okunan buharlaşma değerlerine göre tam sulama yapılan kontrol bitkilerine verilen sulama suyu miktarı aşağıdaki formül yardımıyla belirlenmiştir (Akhoundnejad ve Daşgan, 2019; Dere, 2019). Kuraklık uygulamaları, bunun yarısı ve 1/4'ü kadar su ile yapılmıştır.

$$
I R=A * E \text { pan } * k c p * P
$$

IR: Uygulanan su miktari $\left(\mathrm{m}^{3}\right)$

A: Parsel büyüklüğü (da)

E pan: Buharlaşma miktarı (mm)

kcp: Bitkinin (karpuz) katsayısı (0.80)

P-örtü: Bitki örtüsü (\%)

P-örtü: Bitki taç genişliği $(\mathrm{cm}) /$ Sıra aralığı $(\mathrm{cm})$

Formülden yapılan hesaplamalara göre çalışma boyunca haftada 2 sulama toplamda 23 sulama yapılmıştır. Denemede farklı uygulamalara göre kullanılan su miktarları Çizelge 2'de verilmiştir.

Çizelge 3. Farklı uygulamalarda bitki başına kullanılan su miktarları ( $\left.\mathrm{L} \mathrm{bitki}^{-1}\right)$.

Table 3. The amount of water used in different treatments $\left(\mathrm{L} \mathrm{plant}^{-1}\right)$.

\begin{tabular}{lcccc}
\hline Uygulama & $\begin{array}{c}\text { Stresten önce } \\
(13 \text { Nisan- } \\
\text { 13 Mayı) }\end{array}$ & $\begin{array}{c}\text { Stres sırasında } \\
(14 \text { Mayıs- } \\
11 \text { Temmuz })\end{array}$ & $\begin{array}{c}\text { Yağmur } \\
\text { miktarı }\end{array}$ & $\begin{array}{c}\text { Toplam su } \\
\text { miktarı }\end{array}$ \\
\hline \%100 Kontrol & 47 & 163 & 80 & 290 \\
\%5 Sulama & 47 & 82 & 80 & 209 \\
\%25 Sulama & 47 & 41 & 80 & 168 \\
\hline
\end{tabular}

Çalışmada farklı sulama düzeyleri veya su stresi seviyelerinde karpuz çeşitlerinin kuraklık stresine karşı gösterdikleri tepkileri ortaya koymak için aşağıdaki fizyolojik ölçümler ve bazı bitki büyüme ölçümleri yapılmıştır. Meyve hasatları kaydedilerek toplam verim hesaplanmıştır. Karpuz çeşitlerinde bitkide büyüme ve meyvelerde bazı kalite özelliklerinin kuraklık stresinden etkilenme düzeyleri çeşit bazında ortaya konmuştur. 


\section{Bitkide Büyüme Parametreleri Üzerine Kuraklık Etkisi}

Hasat yapılmadan önce her tekerrürden 10 bitkide, bitki ana gövde uzunluğu ( $\left.\mathrm{cm}^{\text {bitki }}{ }^{-1}\right)$, ana gövdedeki boğum sayısı (adet/bitki), ana gövde taze ağırlığı $\left(\mathrm{g} \mathrm{bitki}^{-1}\right)$ ve toprak seviyesinde ana gövde çapı ( $\mathrm{mm}$ ) ölçülmüştür.

\section{Ana Gövdede Yaprak Alanının Ölçülmesi ( $\mathrm{cm}^{2}$ bitki $\left.^{-1}\right)$}

Hasat yapılmadan önce her tekerrürden 10 bitkide ana gövdesi üzerindeki bütün yapraklar toplanarak labaratuarda Licor marka ve LI-3100 C model yaprak alan ölçer cihaz ile bitki başına $\mathrm{cm}^{2}$ olarak ölçülmüştür (Dere, 2019).

\section{Karpuz Çeşitlerinin Farklı Su Stresi Seviyelerinde Fizyolojik Parametrelerinin Ölçülmesi}

Hasattan önce 10 Temmuz 2019 tarihinde aşağıda anlatılan bir seri fizyolojik ölçümler her tekerrürden 5 bitkide yapılmıştır.

\section{Skala ile Genotiplerin Görsel Olarak Değerlendirilmesi}

Kuraklık stresleri ile yetiştirilen farkı karpuz genotiplerinin, stresten kaynaklanan zararlanmalarının gözle görülen belirtilerini ifade edebilmek amacıyla, 0-5 skala değerlendirmesi yapılmıştır. Skala değerlendirilmesi, bitkilerde su stresi altında ortaya çıkan zararlanmanın derecesini bitkilerin görünüşlerine bakarak ortaya koyabilmek amacıyla yapılmıştır. Bitkilerin zararlanma derecesine göre 0-5 arasında puan verilmiştir (Daşgan ve Akhoundnejad, 2014).

0: Hiç etkilenme yok (kontrol bitkileri)

1: Stresten hafif etkilenme (\%5'den fazla değil),

2: Alt yapraklarda solgunluk başlangıcı olabilir ve etkilenme \%6-20 arası olabilir,

3: Yapraklarda kıvrılma, kapanma, solgunluk ve sararmalar, \%21-50 arası stresten etkilenme olabilir,

4: Yaprakların \%51-80 düzeylerinde şiddetli solgunluk, sararma, yapraklarda nekroz ve kurumalar,

5: Bitkide \%80'in üzerinde geriye dönüşümsüz solma, yapraklarda kurumalar veya ölüm olabilir.

\section{Yaprak Sıcaklığının Ölçülmesi $\left({ }^{\circ} \mathrm{C}\right)$}

Yaprak sıcaklıkları bir infrared termometre yardımı ile bitkilerde ana kol üzerinde uçtan itibaren gelişmesini tamamlamış 3. veya 4. yapraklardan saat $10.00-11.00$ arasında ${ }^{\circ} \mathrm{C}$ cinsinden ölçülerek kaydedilmiştir (Dere, 2019). Ingilizce "Boundary layer" olarak isimlendirilen alan, her bir yaprağı çevreleyen ince bir hava tabakasıdır. Bu tabaka, yaprak ve onu çevreleyen hava arasında gazların ve enerjinin değişim yapıldığı yerdir. Kuraklık stresi genellikle sıcak iklimlerde gerçekleştiği için bitkiler hem su ve hem de sıcak stresi altında adaptasyon yeteneği geliştirmek üzere, transpirasyonu artırarak, yaprak ve "boundary layer" tabakasında sıcaklık düşürmeye çalışırlar bu durum bitkiyi rahatlatmaktadır (Carroll ve ark., 2017).

\section{Yaprakta Membran Zararlanmasının Belirlenmesi (\%)}

Bitki yapraklarında stres durumunda, hücrelerden dışarıya verilen elektroitlerin EC metre ile ölçülmesiyle, membran zararlanma indeksi (MII) hesaplanmıştır (Dlugokecka ve Kacperska-Palacz, 1978; Fan ve Blake, 1994). Bu amaçla, $1 \mathrm{~cm}$ çapındaki yaprak diskleri de-iyonize su içerisinde 4 saat bekletildikten sonra EC ölçülmüş, aynı diskler $100^{\circ} \mathrm{C}^{\prime}$ de 10 dakika bekletildikten sonra, çözeltinin EC değeri tekrar ölçülmüştür. Aşağıdaki formül kullanılarak kontrole göre \% olarak hesaplanmıştır.

$$
\text { Membran Zararlanma İndeksi }=\frac{L t-L c}{1-L c} \times 100
$$

Lt: Kuraklık stresindeki yaprağın otoklav edilmeden önceki EC / Otoklav edildikten sonraki EC

Lc: Kontrol yaprağının otoklav edilmeden önceki EC / Otoklav edildikten sonraki EC

\section{Yaprak Oransal Su içeriğinin Belirlenmesi (\%)}

Yaprak oransal su içeriği (YOSi) yüzde (\%) olarak Sánchez ve ark. (2004) ve Türkan ve ark. (2005)'e göre belirlenmiştir. Karpuz bitkilerinde stres sonunda yaprak örneği alınmış ve oransal su içeriklerinin belirlenebilmesi için, öncelikle taze ağırlıkları alınmış, alınan yaprak 4 saat süre ile saf su içerisinde bekletilmiştir. Saf su içerisinde bekletilen yaprak örnekleri alınıp, kurutulduktan sonra turgor ağırlıkları saptanmıştır. Ağırlıkları alınan yaprak 
örnekleri $65^{\circ} \mathrm{C}$ etüvde 48 saat kurutulduktan sonra, kuru ağırlık g olarak alınmıştır. Elde edilen taze ve kuru ağırlıklar, aşağıdaki formül yardımıyla oranlanarak yaprak oransal su içerikleri (\%) hesaplanmıştır.

$$
\frac{T A-K A}{T u A-K A} x 100
$$

TA: taze ağılık KA: kuru ağırlık TuA: turgor ağırlığı.

\section{Yaprak Su Potansiyelinin Belirlenmesi (MPa)}

Soilmoisture marka taşınabilir bir basınç çemberi cihazı araziye götürülerek, ana sürgün ucundan itibaren 3-4. yapraklarda bar cinsinden su potansiyeli belirlenmiş ve sonra MPa birimine çevrilmiştir (Akhoundnejad ve Daşgan, 2019; Dere, 2019).

\section{Yaprak Osmotik Potansiyelinin Belirlenmesi (MPa)}

Sürgün ucundan 3-4. yapraklardan $1 \mathrm{~g}$ örnek alını $19 \mathrm{~g}$ saf su ile porselen havanda homojenize edilmiştir. Homojenize edilmiş örnek, mikro filtreden geçirilmiş ve Gonatec marka ozmometre cihazında $50 \mu$ kullanılarak donma noktası esasına göre okuma yapılmıştı. Okumalar Osmol $\mathrm{kg}^{-1}$ olarak cihazdan okunup kaydedildikten sonra, bu değerler MPa birimine dönüştürülmüştür (Silva ve ark., 2010; Dere, 2019).

\section{Toplam Karpuz Veriminin Belirlenmesi $\left(\mathrm{kg} \mathrm{da}^{-1}\right)$}

Hasat olgunluğuna ulaşan karpuz meyveleri 11 Temmuz 2019 tarihinde hasat edilmiştir. Elde edilen toplam meyve miktarları parsel alanına oranlanarak dekara verim kg olarak hesaplanmıştır.

\section{Karpuz Meyvelerinde Kalite Analizleri}

Her tekerrürden 5 meyvede ortalama meyve ağırlığı ( $\mathrm{g} /$ meyve), ortalama meyve yüksekliği $(\mathrm{cm})$, ortalama meyve çapı $(\mathrm{cm})$, meyvenin ekvatoral bölgesinden ortalama meyve kabuk kalınlığı $(\mathrm{mm})$ gibi bazı meyve fiziksel özellikleri ölçülmüştür. Ayrıca her parselden 3 meyvede meyve başına sayı olarak tohum miktarı (adet meyve-1) ve meyve başına ağırlık olarak tohum miktarı $\left(\mathrm{g} \mathrm{meyve}^{-1}\right)$ belirlenmiştir.

\section{Meyvede Toplam Kuru Madde Miktarı Belirlenmesi (\%)}

Karpuz meyveleri kesilerek bir dilim ayrılmış ve meyve eti kabuktan ayrılarak taze ağırığı kaydedildikten sonra aluminyum folyo kaplarda $70^{\circ} \mathrm{C}$ etüvde sabit ağırlığa ulaşıncaya kadar kurutulmuştur. $100 \mathrm{~g}$ karpuz meyvesinde, suyu uçurulduktan sonra kalan kısım tartılmış ve ilk ağırlığa oranlanarak kuru madde miktarı (\%) hesaplanmıştır (Dere, 2019).

\section{Meyvede Renk Ölçümleri L, a, b Değerleri}

Karpuz meyve etinde renk analizleri Hunter marka renk ölçer cihazıyla yapılmıştır. Meyvelerin yüzey rengi $L, a$, b Hunter cihazı değerleri ile ifade edilmiştir. Renk ölçer cihazı her ölçüm öncesinde beyaz renkteki ( $L=96.96$, $a=0.08$ ve $b=1.83$ ) seramik tablaya göre kalibre edilmiştir. $L$ (parlaklık), a (yeşillik-kırmızlık) ve $b$ (mavilik-sarılık) durumunu göstermektedir (Gould, 1977). Bu çalışmada karpuz a değerleri pozitif okumalardan oluşmaktadır ve beklendiği gibi kırmızıyı belirtmektedir. Karpuz meyve eti rengi Hunter cihazı b değeri okuması sarı/mavi koordinatıdır ve +b sarıyı, -b ise maviyi belirtmektedir. Bu çalışmada karpuz b değerleri pozitif okumalardan oluşmaktadır ve sarı renge işaret etmektedir. L değerleri ise meyve etinde parlaklığı ifade etmektedir.

\section{Meyve Suyunda pH ve EC Ölçülmesi}

Meyvenin $\mathrm{pH}$ değeri ve içerdiği toplam mineral madde miktarı hakkında bilgiler veren $\mathrm{EC}\left(\mu \mathrm{S} \mathrm{cm}{ }^{-1}\right)$ değeri için $100 \mathrm{ml}$ meyve suyu içerisine $\mathrm{pH}$ metre ve EC metre cihazı elektrotları daldırılarak okunmuştur (Kıran ve ark., 2018).

\section{Meyvede SÇKM Belirlenmesi}

Karpuz meyve suyunda, SÇKM içerikleri dijital refraktometre kullanılarak belirlenmiştir (Karipçin, 2009; Kıran ve ark., 2018; Dere, 2019).

\section{Meteorolojik Veriler}

Deneme alanını temsil eden sıcaklık, nem, ışıklanma ve yağı̧s miktarlarını gösteren meteorolojik veriler Adana Sarıçam Bölge Meteoroloji Müdürlüğü'nden istenmiştir (Çizelge 4). 
Çizelge 4. Deneme alanına ait 2019 yılına ait bazı meteoroloji verileri aylık ortalama değerleri. Table 4. Monthly average meteorological data of the trial area in 2019.

\begin{tabular}{lllll}
\hline Meteoroloji verileri & Nisan & Mayıs & Haziran & Temmuz \\
\hline Aylık minimum sıcaklık $\left({ }^{\circ} \mathrm{C}\right)$ & 12.08 & 18.25 & 22.47 & 24.64 \\
Aylık ortalama sıcaklık $\left({ }^{\circ} \mathrm{C}\right)$ & 17.00 & 24.12 & 27.07 & 28.65 \\
Aylık maksimum sıcaklık $\left({ }^{\circ} \mathrm{C}\right)$ & 23.06 & 31.13 & 32.84 & 34.01 \\
Aylık $10 \mathrm{~cm}$ toprak sıcaklığı $\left({ }^{\circ} \mathrm{C}\right)$ & 19.04 & 27.82 & 31.86 & 34.58 \\
Aylık $20 \mathrm{~cm}$ toprak sıcaklığı ( $\left.{ }^{\circ} \mathrm{C}\right)$ & 18.72 & 27.10 & 31.27 & 33.80 \\
Aylık $50 \mathrm{~cm}$ toprak sıcaklığı ( $\left.{ }^{\circ} \mathrm{C}\right)$ & 17.96 & 24.60 & 29.33 & 31.64 \\
Aylık $100 \mathrm{~cm}$ toprak sıcaklı̆̆ı ( $\left.{ }^{\circ} \mathrm{C}\right)$ & 17.67 & 21.81 & 26.52 & 28.43 \\
Aylık nisbi hava nemi (\%) & 67.00 & 57.64 & 68.70 & 65.40 \\
Aylık yağış miktarı $\left(\mathrm{kg} \mathrm{m}{ }^{-2}\right.$ veya mm) & 1.980 & 0.084 & 0.460 & 0.0 \\
Aylık güneşlenme süresi (saat) & 7.40 & 10.01 & 9.94 & 11.07 \\
\hline
\end{tabular}

\section{Verilerin Değerlendirilmesi}

Deneme sonunda elde edilen veriler JMP paket programında istatistiksel analizleri yapılmış ve ortalamaları LSD testine göre karşılaştııı mıştır (JMP, 2007). Çalışmada \% 100 kontrole göre $\% 50$ ve \% 25 sulamalar ile oluşturulan farklı su stresi ile yetiştirilen karpuz genotiplerinde kaydedilen agronomik, fizyolojik ve pomolojik parametreler, stres olmayan kontrol bitkilerine göre değişimleri yüzde olarak hesaplanmıştır.

\section{BULGULAR VE TARTIŞMA}

Beş adet karpuz çeşidinin \%50 sulama ve \%25 sulama koşullarında yetiştirilmesi ile tam sulama kontrol uygulamasına göre bitki büyümesi, bitkide bazı fizyolojik tepkiler, toplam karpuz verimi ve meyvede bazı kalite parametreleri bakımlarından elde edilen veriler bu bölümde sunulmaktadır.

Karpuz bitkileri \%50 ve \%25 sulama ile yetiştirildiğinde beş çeşidin ortalaması olarak, ana gövde uzunluğunda sırasıyla \%21.86 ve \%25.80 oranında kısalma kaydedilmiştir. 52024 numaralı çeşit \%32.73-40.29 arasında ve Splendit çeşidi \%30.89-44.04 arasında ana kolda kısalma gösterirken, en az kısalma Miracle çeşidinde \%50 sulama uygulamasında \%4.50 olarak kaydedilmiştir. Miracle çeşidinde \%25 sulamada ise \%6 ana kol uzaması belirlenmiştir. Ana gövde uzunluğu bakımından su stresinden en az etkilenme Miracle çeşidinde gözlenmiştir (Çizelge 5). Karipçin (2009) Şanlıurfa ekolojik koşullarında otuz iki farklı karpuz genotipini arazi koşullarında sıfır sulama, \%50 sulama ve \%100 tam sulama (kontrol) koşullarında yetiştirmiş ve genotiplerin kuraklık stresi tepkilerini incelemiştir. Karpuz bitkisi ana gövde boyu sıfır sulamada kontrole göre ortalama ilk yıl \%29 ikinci yıl \%53 azalma gösterirken, \%50 sulama yapılan parsellerde ana gövde boyu kontrole göre ilk yıl \%7 ikinci yıl ise \% 33 azalma göstermiştir. Karipçin (2009)'in iki yıllık verilerinde yıllar arası ana boy uzunluğundaki değişimin varlığı, değişimlerin sadece sulamaya bağlı olmadığını göstermektedir. Genotip ve diğer ekolojik faktörlerin de karpuz bitkisinde ana boy uzunluğu üzerinde etkili olabileceği düşünülmektedir.

Çizelge 5. Su stresi seviyelerinin karpuz bitkisi ana kol uzunluğu ve ana gövdedeki boğum sayısı üzerine etkisi. Table 5. The effects of water stress levels on watermelon main stem length and number of nodes on the main stem.

\begin{tabular}{|c|c|c|c|c|c|c|c|c|c|c|}
\hline \multicolumn{6}{|c|}{ Ana gövde uzunluğu (m) } & \multicolumn{5}{|c|}{$\begin{array}{l}\text { Ana gövde üzerindeki boğum sayısı } \\
\text { (adet bitki-1) }\end{array}$} \\
\hline Çeşit & $\begin{array}{l}\text { \%100 } \\
\text { Sulama } \\
\text { kontrol }\end{array}$ & $\begin{array}{c}\% 50 \\
\text { Sulama }\end{array}$ & $\begin{array}{c}\% 25 \\
\text { Sulama }\end{array}$ & $\begin{array}{c}\text { Kontrole } \\
\text { göre \%50 } \\
\text { sulamada } \\
\text { değişim } \\
\text { (\%) }\end{array}$ & $\begin{array}{c}\text { Kontrole } \\
\text { göre \%25 } \\
\text { sulamada } \\
\text { değişim } \\
\text { (\%) }\end{array}$ & $\begin{array}{c}\% 100 \\
\text { Sulama } \\
\text { kontrol }\end{array}$ & $\begin{array}{c}\% 50 \\
\text { Sulama }\end{array}$ & $\begin{array}{c}\text { \%25 } \\
\text { Sulama }\end{array}$ & $\begin{array}{c}\text { Kontrole } \\
\text { göre \%50 } \\
\text { sulamada } \\
\text { değişim } \\
\text { (\%) }\end{array}$ & $\begin{array}{c}\text { Kontrole } \\
\text { göre \%25 } \\
\text { sulamada } \\
\text { değişim } \\
\text { (\%) }\end{array}$ \\
\hline 52024 & $2.78 \mathrm{a}$ & $1.66 \mathrm{~b}$ & 1.87 & -40.29 & -32.73 & $35.3 b$ & $25.1 \mathrm{bc}$ & $26.9 \mathrm{~b}$ & -28.93 & -23.95 \\
\hline Minipool & $2.27 \mathrm{bc}$ & 1.74 b & 1.64 & -23.35 & -27.75 & $28.8 \mathrm{c}$ & $22.7 \mathrm{c}$ & $23.6 \mathrm{~b}$ & -21.23 & -18.14 \\
\hline Miracle & $2.00 \mathrm{c}$ & $1.91 b$ & 2.12 & -4.50 & 6.00 & $32.1 \mathrm{bc}$ & $31.0 \mathrm{ab}$ & $30.7 \mathrm{a}$ & -3.46 & -4.48 \\
\hline Splendit & $3.27 b c$ & $2.26 \mathrm{a}$ & 1.83 & -30.89 & -44.04 & $44.0 \mathrm{a}$ & $32.7 \mathrm{a}$ & $22.8 \mathrm{~b}$ & -25.75 & -48.23 \\
\hline Starburst & $2.43 b$ & $2.18 \mathrm{a}$ & 1.69 & -10.29 & -30.45 & $32.0 \mathrm{bc}$ & $29.4 \mathrm{ab}$ & $25.3 \mathrm{~b}$ & -8.00 & -20.84 \\
\hline Ortalama & 2.55 & 1.95 & 1.83 & -21.86 & -25.80 & 34.4 & 28.2 & 25.8 & -17.47 & -23.13 \\
\hline $\mathrm{LSD}_{0.05}$ & 0.31 & 0.26 & Ö.D.* & - & - & 4.11 & 6.33 & 3.04 & - & - \\
\hline$P$ & 0.0016 & 0.0025 & 0.1771 & - & - & 0.0003 & 0.0317 & 0.0157 & - & - \\
\hline
\end{tabular}

*Ö.D.: önemli değil. 
Su stresi ile yetişen karpuz bitkilerinde ana gövde üzerindeki boğum sayısı \%50 ve \%25 sulamada kontrole göre sırasıyla \%17.47 ve \%23.13 oranında azalma göstermiştir. En fazla boğum azalması \%25.75-48.23 arasında Splendit çeşidinde görülmüştür. Miracle çeşidinde boğum sayısı kontrole göre \%3.46-4.48 arasında azalma göstererek su stresinden boğum sayısı en az etkilenen çeşit olmuştur (Çizelge 5). Karipçin (2009)'nin otuz iki farklı karpuz genotipi ile arazi koşullarında yürüttüğü çalışmada, karpuz bitkisi ana gövde üzerindeki boğum sayısı sıfır sulamada kontrole göre ortalama ilk yıl \%1.21 ikinci yıl \%52 azalma gösterirken, \%50 sulama yapılan parsellerde boğum sayısı kontrole göre ilk yıl \%9.3 ikinci yıl ise \%33.8 azalma göstermiştir.

Karpuz bitkisi ana gövde çapı \%50 ve \%25 sulama uygulamalarında beş çeşit ortalaması olarak sırasıyla \%9.18 ile \%11.89 oranında azalma göstermiştir. Dört çeşitte gövde çapı streste azalırken, sadece Starburst çeşidi her iki su stresi uygulamasında da kontrole göre yaklaşık \%2.99 gövde kalınlığında artış göstermiştir (Çizelge 5).

Karipçin (2009), karpuz genotiplerinde bitki ana gövde çapının sıfır sulamada kontrole göre ilk yıl ortalama \%47 ikinci yı \%58 azalma gösterdiğini, \%50 sulama yapılan parsellerde ise ana gövde çapının kontrole göre ilk yıl ortalama \%27 ikinci yıl ise \%43 azaldığını bildirmiştir.

Karpuz bitkilerinin farklı su stresi seviyelerinde görsel olarak zararlanma durumlarını gösteren 0-5 skalası değerlendirmesine göre, beş çeşidin ortalaması olarak \%50 ve \%25 sulama uygulamalarında skala değerleri sırasıyla 3.48 ve 3.55 olarak kaydedilmiştir (Çizelge 6). Skala sınıfları 0'dan 5' doğru ilerledikçe zarar artmaktadır. Kontrol uygulamalarına göre en fazla görsel zararlanmanın Minipool çeşidinde olduğu, bunu 52024 numaralı çeşidin izlediği görülmektedir. Görsel olarak en az yeşil aksam zararlanması \%50 sulama stresinde Splendit çeşidinde görülürken bunu Minipool izlemiştir. 52024 çeşidinde Starburst ve Miracle çeşitlerinden biraz daha fazla yeşil aksam zararlanması göstermiştir (Çizelge 6).

Çizelge 6. Su stresi seviyelerinin karpuz bitkisinde ana gövde çapı ve görsel olarak kurak zararlanması 0-5 skala puanlanması ( 0 en iyi 5 en kötü) ve üzerine etkisi.

Table 6. The effects of water stress on main stem diameter and visual drought damage 0-5 scale scoring (0 best 5 worst) in watermelon plant.

\begin{tabular}{|c|c|c|c|c|c|c|c|c|c|c|}
\hline \multicolumn{7}{|c|}{ Ana gövde çapı (mm) } & \multicolumn{4}{|c|}{ Görsel olarak 0-5 skala puanlanması** } \\
\hline Çeşit & $\begin{array}{l}\text { \%100 } \\
\text { Sulama } \\
\text { kontrol }\end{array}$ & $\begin{array}{l}\% 50 \\
\text { Sulama }\end{array}$ & $\begin{array}{l}\text { \%25 } \\
\text { Sulama }\end{array}$ & $\begin{array}{r}\text { Kontrole } \\
\text { göre \%50 } \\
\text { sulamada } \\
\text { değişim } \\
(\%)\end{array}$ & $\begin{array}{r}\text { Kontrole } \\
\text { göre \%25 } \\
\text { sulamada } \\
\text { değişim } \\
(\%)\end{array}$ & $\begin{array}{l}\text { \%100 } \\
\text { Sulama } \\
\text { kontrol }\end{array}$ & $\begin{array}{l}\text { \%50 } \\
\text { Sulama }\end{array}$ & $\begin{array}{l}\text { \%25 } \\
\text { Sulama }\end{array}$ & $\begin{array}{r}\text { Kontrole } \\
\text { göre \%50 } \\
\text { sulamada } \\
\text { değişim } \\
(\%)\end{array}$ & $\begin{array}{r}\text { Kontrole } \\
\text { göre \%25 } \\
\text { sulamada } \\
\text { değişim } \\
(\%)\end{array}$ \\
\hline 52024 & 40.20 & 38.87 & 35.56 & -3.31 & -11.54 & 1.67 & $3.89 \mathrm{a}$ & 3.91 & 133 & 134 \\
\hline Minipool & 38.81 & 32.88 & 31.59 & -15.28 & -18.60 & 1.07 & $3.44 \mathrm{~b}$ & 3.73 & 221 & 249 \\
\hline Miracle & 44.76 & 38.25 & 37.81 & -14.54 & -15.53 & 1.65 & $3.55 a$ & 3.56 & 115 & 116 \\
\hline Splendit & 44.87 & 37.81 & 37.45 & -15.73 & -16.54 & 1.42 & 3.08 bc & 3.04 & 117 & 114 \\
\hline Starburst & 40.16 & 41.36 & 41.26 & 2.99 & 2.74 & 1.56 & $3.46 \mathrm{a}$ & 3.49 & 122 & 124 \\
\hline Ortalama & 41.76 & 37.83 & 36.73 & -9.18 & -11.89 & 1.47 & 3.48 & 3.55 & 142 & 147 \\
\hline $\mathrm{LSD}_{0.05}$ & Ö.D.* & Ö.D.* & Ö.D.* & - & - & Ö.D.* & 0.38 & Ö.D.* & - & - \\
\hline$P$ & 0.1634 & 0.2322 & 0.1463 & - & - & 0.158 & 0.0020 & 0.555 & - & - \\
\hline
\end{tabular}

*Ö.D.: önemli değil. **:(0 en iyi 5 en kötü).

Su stresi seviyelerinin ana gövde taze ağırlığı üzerine etkisi beş çeşit ortalaması olarak \%50 ve \%25 sulamalarda sırasıyla \%4.44 ve \%36.60 düzeylerinde azalma olarak kaydedilmiştir (Çizelge 7). Bitkiler su stresinin daha fazla olduğu \%25 sulamada daha fazla ağırlık kaybı göstermiştir. Ancak, Miracle ve Splendit çeşitleri diğer çeşitlere göre biraz daha farklı davranmıştır. Miracle çeşidinde azalma olmamış aksine $\% 50$ ve $\% 25$ sulamalarda sırasıyla \%33.33 ve \%6.67 ağırlık artışı olmuştur. Splendit çeşidinde ise \%50 sulamada ana kol ağırlığı \%40 artmış ve \%25 sulamada ise \%13.75 azalmıştır (Çizelge 7). Mo ve ark. (2016a), 16 farklı karpuz genotipi ile saksıda kuraklık çalışması yapmıştır. Karpuz genotipleri kurak stresi tepkisi bakımından büyük farklıık sergilemiştir. Genotip bazında kuraklık stresinden etkilenme düzeyleri ve stres zararı farklı olmuştur. Kuraklık stresi, çoğu genotip için kök/yeşil aksam oranını artıırken, bitki boyu, yeşil aksam ve kök taze ve kuru ağırığı azalmıştır. Bazı genotiplerde kök uzunluğu kütlesi artmıştır. Kuraklık stresine genotiplerin cevabı farklı olabilmekle birlikte taze ağırlıklardaki değişimin hava oransal nemi, rüzgar yönü ve şiddeti gibi ekolojik faktörlerle birlikte değerlendirilmesi gerekir.

Karpuz bitkilerinde ana gövde üzerindeki toplam yaprak alanı \%50 ve \%25 sulama uygulamalarında beş çeşit ortalaması olarak kontrole göre sırasıyla \%11.24 ve \%35.14 oranında azalma göstermiştir (Çizelge 7). Beklendiği gibi bitkilerin \%25 sulamada daha fazla yaprak alanı kaybı olmuştur. Ancak, Miracle ve Splendit çeşitlerinde diğerlerine göre farklı olarak; Miracle'da \% 50 ve \% 25 sulamada yaprak alanı sırasıyla \% 13.46 ve \% 10.02 artmıştır. 
Splendit çeşidinde \%50 sulamada yaprak alanı \%18.86 artmış ve \%25 sulamada ise sadece \% 2.96 azalma kaydedilmiştir. Ana gövde üzerindeki yaprak alanı azalması en çok Minipool çeşidinde yaklaşık \%43.14-61.98 arasında gerçekleşmiştir (Çizelge 7). Mo ve ark. (2016b), kurak stresine dayanıklı yabani karpuz ve duyarlı kültür karpuzu ile yaptıkları kurak stresi denemesinde, karpuz bitkilerinin kurak stresinde kök/yeşil aksam oranını artırdıklarını, fotosentez ürünlerini daha çok köke gönderdiklerini ve kökü büyütmeye çalışarak su kaybına neden olacak yeşil aksam ve özellikle yaprak alanını azaltma eğilimine girdiklerini bildirmiştir. Karipçin (2009)'nin yürüttüğü çalışmada, karpuz bitkilerinde yaprak alanı sıfır sulamada kontrole göre ortalama ilk yıl \%75 ikinci yıl \%79 azalma gösterirken, \%50 sulama yapılan parsellerde bitki yaprak alanı kontrole göre ilk yıl \%45 ikinci yıl ise \%48 azalma göstermiştir.

Çizelge 7. Su stresi seviyelerinin karpuz bitkisinin ana gövde taze ağırlığı ( $\left(\right.$ bitki $\left.^{-1}\right)$ ve ana gövde üzerindeki toplam yaprak alanı üzerine etkisi $\left(\mathrm{cm}^{2}\right.$ bitki $\left.{ }^{-1}\right)$.

Table 7. The effects of water stress levels on the main stem fresh weight $\left(\mathrm{g} \mathrm{plant}{ }^{-1}\right)$ and total leaf area $\left(\mathrm{cm}^{2}\right.$ plant $\left.{ }^{-1}\right)$ of watermelon plant.

\begin{tabular}{|c|c|c|c|c|c|c|c|c|c|c|}
\hline \multirow[b]{2}{*}{ Çeşit } & \multicolumn{5}{|c|}{ Ana gövde taze ağırlığı (g bitki $\left.{ }^{-1}\right)$} & \multicolumn{5}{|c|}{$\begin{array}{l}\text { Ana gövde üzerindeki toplam yaprak alanı } \\
\left(\mathrm{cm}^{2} \text { bitki }^{-1}\right)\end{array}$} \\
\hline & $\begin{array}{l}\% 100 \\
\text { Sulama } \\
\text { kontrol }\end{array}$ & $\begin{array}{l}\text { \%50 } \\
\text { Sulama }\end{array}$ & $\begin{array}{l}\% 25 \\
\text { Sulama }\end{array}$ & $\begin{array}{l}\text { Kontrole } \\
\text { göre \%50 } \\
\text { sulamada } \\
\text { değişim } \\
(\%)\end{array}$ & $\begin{array}{r}\text { Kontrole } \\
\text { göre \%25 } \\
\text { sulamada } \\
\text { değişim } \\
(\%)\end{array}$ & $\begin{array}{l}\% 100 \\
\text { Sulama } \\
\text { kontrol }\end{array}$ & $\begin{array}{l}\text { \%50 } \\
\text { Sulama }\end{array}$ & $\begin{array}{l}\% 25 \\
\text { Sulama }\end{array}$ & $\begin{array}{l}\text { Kontrole } \\
\text { göre \%50 } \\
\text { sulamada } \\
\text { değişim } \\
\text { (\%) }\end{array}$ & $\begin{array}{l}\text { Kontrole } \\
\text { göre \%25 } \\
\text { sulamada } \\
\text { değişim } \\
\text { (\%) }\end{array}$ \\
\hline 52024 & 133 & 115 & 67 & -13.53 & -49.62 & 2796 & 2408 & 1398 & -13.88 & -50.00 \\
\hline Minipool & 114 & 65 & 44 & -42.98 & -61.40 & 2404 & 1367 & 914 & -43.14 & -61.98 \\
\hline Miracle & 90 & 120 & 96 & 33.33 & 6.67 & 1827 & 2073 & 2010 & 13.46 & 10.02 \\
\hline Splendit & 80 & 112 & 69 & 40.00 & -13.75 & 1654 & 1966 & 1605 & 18.86 & -2.96 \\
\hline Starburst & 124 & 105 & 67 & -15.32 & -45.97 & 2613 & 2210 & 1398 & -15.42 & -46.50 \\
\hline Ortalama & 108 & 103 & 69 & -4.44 & -36.60 & 2259 & 2005 & 1465 & -11.24 & -35.14 \\
\hline $\mathrm{LSD}_{0.05}$ & 18.935 & 30.278 & 15.815 & - & - & 412.09 & 505.96 & 331.365 & - & - \\
\hline$P$ & $<0.0001$ & 0.0083 & $<0.0001$ & - & - & $<0.0001$ & 0.0047 & $<0.0001$ & - & - \\
\hline
\end{tabular}

Denemede, karpuz yapraklarında sıcaklık kontrole göre \%50 ve \%25 sulanan bitkilerde sırasıyla \%5.37 ve \%14.72 arasında düşürülmüştür. Bitkiler \%25 sulamada daha fazla yaprak sıcaklığı düşürmüştür; buna göre en fazla yaprak sıcaklığı düşüren karpuz çeşidi, \%23.83 ile Splendit ve sonra \% 18.15 ile Miracle çeşitleri olduğu görülmektedir. Kontrole kıyasla \%25 sulama uygulamasında yaprak sıcaklığını en az düşüren çeşidin Minipool olduğu belirlenmiştir (Çizelge 8). Karipçin (2009) karpuz genotiplerinde yaprak sıcaklığının iki yıl tekrar edilen denemelerde ortalama olarak, sıfir sulamada $33-41^{\circ} \mathrm{C}$ arasında, $\% 50$ sulamada $30-36^{\circ} \mathrm{C}$ arasında ve $\% 100$ sulama kontrol uygulamasında ise $27-31^{\circ} \mathrm{C}$ arasında değiştiğini bildirmiştir. Kurak stresi genellikle sıcak iklimlerde gerçekleştiği için yaprak sıcaklığının düşürülmesi bitkileri serinleten ve rahatlatan bir fizyolojik tepkidir, tolerant genotiplerde aranan bir özelliktir (Akhoundnejad and Daşgan, 2019).

Kuraklık stresi altındaki karpuz bitkilerinin yaprak hücrelerindeki membran zararlanması \%50 ve \%25 sulama uygulamalarında beş çeşidin ortalaması olarak sırasıyla kontrole göre \%34.31 ve \%33.18 oranlarında artmıştır. Çeşitler bazında incelendiğinde Miracle ve Splendit çeşitleri \%25 sulamada sırasıyla kontrole göre \%9.39 ve \%7.14 gibi düşük düzeylerde membran zararlanması ile dikkat çektiği görülmektedir. Aynı koşullarda 52024, Minipool ve Starburst çeşitlerinin \%25 sulama uygulamasında membran zararlanma oranları kontrole göre sırasıyla \% 44.29, \% 50.95 ve \% 54.11 gibi yüksek seviyelerde gerçekleşmiştir (Çizelge 8).

Karpuz yapraklarında oransal su içeriği \%50 ve \%25 sulama uygulamalarında beş çeşidin ortalaması olarak sırasıyla \%2.92 ve \%8.74 azalmıştır. Su stresi arttıkça yaprakta oransal su azalmıştır. Çeşitler \%0.95 ile \%25.39 arasında su kaybederken, en fazla su kaybı Minipool ve 52024 çeşitlerinde gözlenmiştir. Illginç olarak, Splendit ve Miracle çeşitlerinde diğer üç çeşitten farklı olarak kontrole göre yaprak oransal su içeriğinde bir miktar artışlar göstermiştir. Splendit çeşidinde \%1.19-1.89 oranında az bir artış varken, Miracle çeşidinde ise \%5.52-9.48 oranında yaprak oransal su içeriği artmıştır (Çizelge 9). Mo ve ark. (2016a), 16 farklı karpuz genotipi ile yaptıkları çalışmada, kurak stresi altında karşılaştırılan genotiplerde yaprak oransal su içeriği genel bir düşme göstermiş ve klorofil, prolin ve antioksidan enzim aktiviteleri artış göstermiştir. Karipçin (2009), karpuz genotiplerinde yaprak oransal su içeriğini iki yıl tekrar edilen denemelerde genotip ortalaması olarak, sıfır sulamada \%47-63 arasında, \%50 sulamada \%67-71 arasında ve \%100 sulama kontrol uygulamasında ise \%79-82 arasında değiştiğini bildirmiştir. 
Çizelge 8. Su stresi seviyelerinin karpuz bitkisinin yaprak sıcaklığı $\left({ }^{\circ} \mathrm{C}\right)$ ve yaprak hücrelerinde membran zararlanması (\%) üzerine etkisi.

Table 8. The effects of water stress on leaf temperature $\left({ }^{\circ} \mathrm{C}\right)$ and membrane damage (\%) in leaf cells of watermelon plant.

\begin{tabular}{|c|c|c|c|c|c|c|c|c|c|c|}
\hline \multirow[b]{2}{*}{ Çeşit } & \multicolumn{4}{|c|}{ Yaprak sıcaklığı ( $\left.{ }^{\circ} \mathrm{C}\right)$} & \multicolumn{6}{|c|}{ Yaprak hücrelerinde membran zararlanması (\%) } \\
\hline & $\begin{array}{l}\text { \%100 } \\
\text { Sulama } \\
\text { kontrol }\end{array}$ & $\begin{array}{l}\% 50 \\
\text { Sulama }\end{array}$ & $\begin{array}{l}\text { \%25 } \\
\text { Sulama }\end{array}$ & $\begin{array}{r}\text { Kontrole } \\
\text { göre \%50 } \\
\text { sulamada } \\
\text { değişim } \\
(\%)\end{array}$ & $\begin{array}{r}\text { Kontrole } \\
\text { göre \%25 } \\
\text { sulamada } \\
\text { değişim } \\
(\%)\end{array}$ & $\begin{array}{l}\text { \%100 } \\
\text { Sulama } \\
\text { kontrol }\end{array}$ & $\begin{array}{l}\% 50 \\
\text { Sulama }\end{array}$ & $\begin{array}{l}\text { \%25 } \\
\text { Sulama }\end{array}$ & $\begin{array}{r}\text { Kontrole } \\
\text { göre \%50 } \\
\text { sulamada } \\
\text { değişim } \\
(\%)\end{array}$ & $\begin{array}{r}\text { Kontrole } \\
\text { göre \%25 } \\
\text { sulamada } \\
\text { değişim } \\
(\%)\end{array}$ \\
\hline 52024 & $35.98 \mathrm{ab}$ & 31.02 & $31.78 \mathrm{a}$ & -13.79 & -11.67 & $15.6 \mathrm{~d}$ & $20.7 c$ & $22.5 \mathrm{c}$ & 32.67 & 44.29 \\
\hline Minipool & $37.06 \mathrm{a}$ & 34.31 & 33.68 a & -7.42 & -9.12 & $17.9 \mathrm{bc}$ & $21.5 c$ & $27.0 \mathrm{ab}$ & 20.19 & 50.95 \\
\hline Miracle & $34.27 b$ & 33.09 & $28.05 \mathrm{~b}$ & -3.44 & -18.15 & $20.3 a$ & $24.3 \mathrm{~b}$ & $22.3 \mathrm{~cd}$ & 19.47 & 9.39 \\
\hline Splendit & $35.63 \mathrm{ab}$ & 31.90 & $27.14 \mathrm{~b}$ & -10.47 & -23.83 & $19.3 \mathrm{ab}$ & $26.1 \mathrm{a}$ & $20.7 d$ & 34.97 & 7.14 \\
\hline Starburst & $31.01 \mathrm{c}$ & 33.57 & $27.65 b$ & 8.26 & -10.84 & $16.3 \mathrm{~cd}$ & $26.8 \mathrm{a}$ & $25.1 \mathrm{~b}$ & 64.23 & 54.11 \\
\hline Ortalama & 34.79 & 32.78 & 29.66 & -5.37 & -14.72 & 17.9 & 23.9 & 23.5 & 34.31 & 33.18 \\
\hline $\mathrm{LSD}_{0.05}$ & 1.82 & Ö.D.* & 2.684 & - & - & 1.904 & 1.283 & 1.6353 & - & - \\
\hline$P$ & 0.0011 & 0.3125 & 0.0052 & - & - & 0.0020 & $<0.0001$ & 0.0001 & - & - \\
\hline
\end{tabular}

*Ö.D.: önemli değil.

Yaprak su potansiyeli ölçüm değerleri negatif MPa olarak küçüldükçe yaprak su içeriği azalmaktadır. Karpuz çeşitlerinde yaprak su potansiyeli \%50 ve \%25 sulama uygulamalarında kontrole göre beş çeşit ortalaması olarak sırasıyla \%95.16 ve \% 109.52 düşmüştür. Yaprak su potansiyeli bakımından en iyi durumda olan genotip, Miracle en dezavantajlı ise Splendit olarak görülmektedir (Çizelge 9). Bu ölçümün gün içerisinde hangi saatte ve bitkinin hangi gelişme aşamasında yapıldığı önemlidir. Denemede vegetasyon sonunda hasat aşamasında ve saat $10.00-$ 11.00 arasında yapılmıştır. Ölçümlerin çalışmanın son döneminde yapılmış olması nedeniyle yaprak su potansiyelinin düşük değerlerde olduğu kanısına varılmıştır. Karipçin (2009), karpuz genotiplerinde yaprak su potansiyelini iki yıl tekrar edilen denemelerde genotip ortalaması olarak, sıfır sulamada -0.84 bar ile -2.47 bar arasında, \%50 sulamada -0.50 bar ile -1.36 bar arasında ve \%100 sulama kontrol uygulamasında ise -0.25 bar ile -0.72 bar arasında yer aldığını rapor etmiştir.

Çizelge 9. Su stresi seviyelerinin karpuz bitkisinin yaprak oransal su içeriği ve yaprak su potansiyeli üzerine etkisi. Table 9. The effects of water stress levels on leaf water content and leaf water potential of watermelon plant.

\begin{tabular}{|c|c|c|c|c|c|c|c|c|c|c|}
\hline \multirow[b]{2}{*}{ Çeşit } & \multicolumn{6}{|c|}{ Yaprak oransal su içeriği (\%) } & \multicolumn{4}{|c|}{ Yaprak su potansiyeli (MPa) } \\
\hline & $\begin{array}{l}\text { \%100 } \\
\text { Sulama } \\
\text { kontrol }\end{array}$ & $\begin{array}{l}\text { \%50 } \\
\text { Sulama }\end{array}$ & $\begin{array}{l}\text { \%25 } \\
\text { Sulama }\end{array}$ & $\begin{array}{r}\text { Kontrole } \\
\text { göre \%50 } \\
\text { sulamada } \\
\text { değişim } \\
(\%)\end{array}$ & $\begin{array}{r}\text { Kontrole } \\
\text { göre \%25 } \\
\text { sulamada } \\
\text { değişim } \\
(\%)\end{array}$ & $\begin{array}{l}\text { \%100 } \\
\text { Sulama } \\
\text { kontrol }\end{array}$ & $\begin{array}{l}\text { \%50 } \\
\text { Sulama }\end{array}$ & $\begin{array}{l}\% 25 \\
\text { Sulama }\end{array}$ & $\begin{array}{r}\text { Kontrole } \\
\text { göre \%50 } \\
\text { sulamada } \\
\text { değişim } \\
(\%)\end{array}$ & $\begin{array}{r}\text { Kontrole } \\
\text { göre \%25 } \\
\text { sulamada } \\
\text { değişim } \\
(\%)\end{array}$ \\
\hline 52024 & $91.5 \mathrm{a}$ & $90.7 \mathrm{a}$ & $76.3 \mathrm{ab}$ & -0.95 & -16.65 & $-0.16 a$ & $-0.29 a$ & -0.40 & -81.25 & -150.00 \\
\hline Minipool & $90.6 \mathrm{a}$ & $81.9 \mathrm{~b}$ & $67.6 c$ & -9.60 & -25.39 & $-0.19 a$ & $-0.35 b$ & -0.35 & -84.21 & -84.21 \\
\hline Miracle & $70.5 b$ & $74.4 \mathrm{~cd}$ & $77.2 \mathrm{a}$ & 5.52 & 9.48 & $-0.25 b$ & $-0.32 a b$ & -0.46 & -28.00 & -84.00 \\
\hline Splendit & $74.1 \mathrm{~b}$ & $75.0 \mathrm{~d}$ & $75.5 \mathrm{~b}$ & 1.19 & 1.89 & $-0.17 a$ & $-0.42 c$ & -0.40 & -147.06 & -135.29 \\
\hline Starburst & $88.3 \mathrm{a}$ & 78.8 bc & $76.8 \mathrm{ab}$ & -10.75 & -13.04 & $-0.17 a$ & $-0.40 c$ & -0.33 & -135.29 & -94.12 \\
\hline Ortalama & 83.0 & 80.14 & 74.67 & -2.92 & -8.74 & -0.19 & -0.36 & -0.39 & -95.16 & -109.52 \\
\hline $\mathrm{LSD}_{0.05}$ & 6.72 & 3.61 & 1.65 & - & - & 0.12 & 0.53 & Ö.D.* & - & - \\
\hline P & 0.0002 & 0.0001 & $<0.0001$ & - & - & 0.0004 & 0.0018 & 0.0757 & - & - \\
\hline
\end{tabular}

*Ö.D.: önemli değil.

Yaprak osmotik potansiyeli bakımından denemede en avantajı genotip Miracle olarak belirlenmiştir. Miracle, kontrole göre osmotik potansiyeli \%50 ve \%25 sulama uygulamalarında sırasıyla 27.78 ve $\% 91.67$ artırmıştır (Çizelge 10). Starburst, ve 52024 nolu çeşitler de yaprak osmotik potansiyeli bakımından avantajlı görülürken, Minipool kontrole göre en dezavantajlı çeşit olmuştur. Splendit çeşidi ise \%50 sulama uygulamasında yaprak osmotik potansiyelini azaltmıştır. Mo ve ark. (2016b), kurak stresine dayanıklı yabani karpuz ve duyarlı kültür karpuzu ile yaptıkları kurak stresi denemesinde, strese dayanıklı olan yabani karpuzun osmoregülasyonu çok iyi düzenlediğini bildirmiştir. Yaprak osmotik potansiyeli ile yaprak su potansiyeli arasında ters bir ilişki 
bulunmaktadır. Kuraklık stresinde dayanıklı genotiplerde hücre içerisinde, çözülebilir organik ve inorganik maddelerin artarak biriktirilmesi "osmotik düzenleme" ve "osmotik potansiyelin artırılması" (negatif MPa değeri küçülmesi) anlamına gelmektedir. Osmotik düzenleme bitkide su alımını artırarak yaprağın turgor durumunu desteklemektedir. Yaprak osmotik potansiyeli için negatif MPa olarak değer küçüldükçe madde miktarı artmakta bitki için osmotik düzenleme daha avantajlı olmaktadır (Akhoundnejad ve Daşgan, 2019).

Çizelge 10. Su stresi seviyelerinin karpuz bitkisinin yaprak osmotik potansiyeli (MPa) üzerine etkisi. Table 10. The effect of water stress levels on leaf water potential of watermelon plant (MPa).

\begin{tabular}{|c|c|c|c|c|c|}
\hline \multicolumn{6}{|c|}{ Yaprak osmotik potansiyeli (MPa) } \\
\hline Çeşit & $\begin{array}{l}\% 100 \\
\text { Sulama Kontrol }\end{array}$ & $\% 50$ Sulama & \%25 Sulama & $\begin{array}{r}\text { Kontrole göre \%50 } \\
\text { sulamada değişim } \\
(\%)\end{array}$ & $\begin{array}{r}\text { Kontrole göre \%25 } \\
\text { sulamada değişim } \\
\text { (\%) }\end{array}$ \\
\hline 52024 & $-3.3 a$ & $-3.1 \mathrm{a}$ & $-4.5 b$ & 6.06 & -36.36 \\
\hline Minipool & $-3.2 \mathrm{a}$ & $-2.9 a$ & $-2.6 \mathrm{a}$ & 9.38 & 18.75 \\
\hline Miracle & $-3.6 a b$ & $-4.6 c$ & $-6.9 c$ & -27.78 & -91.67 \\
\hline Splendit & $-4.3 b$ & $-3.1 \mathrm{a}$ & $-4.8 b$ & 27.91 & -11.63 \\
\hline Starburst & $-3.4 \mathrm{a}$ & $-3.9 b$ & $-4.1 a b$ & -14.71 & -20.59 \\
\hline Ortalama & -3.56 & -3.52 & -4.58 & 0.17 & -28.30 \\
\hline $\mathrm{LSD}_{0.05}$ & Ö.D.* & 0.58 & 1.66 & - & - \\
\hline$P$ & 0.057 & 0.0006 & 0.004 & - & - \\
\hline
\end{tabular}

*Ö.D.: önemli değil.

\section{Karpuz Meyve Kalitesi Üzerine Kuraklık Stresinin Etkileri}

Beş çeşidin ortalama karpuz meyve ağırlığı, \%50 ve \%25 sulama uygulamalarında sırasıyla kontrole göre \% 12.11 ve \% 12.24 oranında azalmıştır. Çeşit bazında incelendiğinde, meyve ağırlığı bakımından en az etkilenen çeşidin Splendit olduğu görülmektedir. Bu çeşitte \%50 su stresinde karpuz ağırlığı \%15.36 artmış ve \%75 su stresinde ise meyve ağırlığı sadece \% 6.09 azalmıştır (Çizelge 11). Meyve ağırlığının \%50 su stresinde \%12.55 arttığı diğer bir çeşit ise 52024 olmuştur. Ancak, \%75 su stresinde bu çeşidin meyve ağırlığı \%33.47 oranında azalmıştır. Miracle çeşidinde karpuz ağırlığı \%50 su stresinde \%27.42 azalırken, \%75 su stresinde kontrole göre hiç değişme kaydedilmemiştir. Starbust çeşidinde de benzer bir durum görülmüş \%50 su stresinde karpuz ağırlığı \%28.91 azalırken, \%75 su stresinde ise çok az, sadece \%0.86 azalma kaydedilmiştir. Said ve Fatiha (2018) beş yöresel ve dört hibrit olmak üzere dokuz karpuz genotipi ile arazide kontrol ve \%50 kısıtlı sulama koşullarında deneme yapmış ve meyve özelliklerinin su stresinden etkilenmesini incelemişlerdir. Meyve ağırlığı 9 genotip ortalaması olarak kontrolde $5.65 \mathrm{~kg}$ ve \%50 su stresi olan uygulamada ise $4.05 \mathrm{~kg}$ olmuş, kontrole göre karpuz meyve ağırlığı \%28.8 azalmıştır. Karipçin (2009), karpuz genotiplerinde birinci ve ikinci yıl ortalama karpuz ağırlı̆ının sırasıyla sıfır sulama yapılan parsellerde $2.67-2.83 \mathrm{~kg}$, \%50 sulama yapılan parsellerde $5.41-5.49 \mathrm{~kg}$ ve \%100 sulama yapılan kontrol parsellerinde ise, $7.59-7.27 \mathrm{~kg}$ olduğunu bildirmiştir. Kontrol uygulamasına göre sıfır sulanan parsellerde meyve ağırlığı azalması iki yıl denemesinde sırasıyla \%65-61 arasında ve \%50 sulanan parsellerde kontrole göre meyve ağırlığı azalması \%28-25 olarak rapor edilmiştir.

Genel olarak karpuz meyve yüksekliğinin su stresinden etkilendiği ve sulama \%50'den \%25'e doğru azaldıkça meyve yüksekliğinin azalma eğiliminde olduğu gözlenmiştir. Buna göre beş çeşidin ortalaması olarak \%50 sulamada meyve yüksekliği kontrole göre \%3.83 azalırken sulamanın \%25 olduğu uygulamada meyve yüksekliği \%10.99 azalmıştır. Çeşit bazında meyve yüksekliği bakımından en fazla olumsuz etkilenen çeşit, Minipool olurken en az etkilenen ise Splendit olmuştur. Miracle çeşidinde ise kontrole göre su stresinde meyve yüksekliğinde \%1.088.24 arasında artışlar kaydedilmiştir (Çizelge 11). Said ve Fatiha (2018) beş yöresel ve 4 hibrit olmak üzere dokuz karpuz genotipi ile arazide kontrol ve \%50 kısıtlı sulama koşullarında yaptıkları denemede su stresinin meyve özelliklerine etkilerini incelemişlerdir. Meyve yüksekliği 9 genotip ortalaması olarak kontrolde $27.37 \mathrm{~cm}$ ve \%50 su stresi olan uygulamada ise $24.36 \mathrm{~cm}$ olmuş, kontrole göre karpuzda meyve yüksekliği \%11 azalmıştır. Karipçin (2009) karpuz genotiplerinde sıfır sulama yapılan parsellerin ortalama meyve yüksekliği 14.16-14.78 cm, \%50 sulama yapılan parsellerdeki meyve yüksekliği $21.30-21.37 \mathrm{~cm}$ ve $\% 100$ sulama yapılan kontrol parsellerinde meyve yüksekliği $28.64-28.24 \mathrm{~cm}$ olarak bildirilmiştir. Kontrol uygulamasına göre sıfır sulanan parsellerde meyve yüksekliğinin azalması iki yıl denemesinde sırasıyla \%51-48 arasında ve \%50 sulanan parsellerde kontrole göre meyve yüksekliğinin azalması ise \%26-24 olarak rapor edilmiştir. 
Çizelge 11. Su stresi seviyelerinin karpuz bitkisinin meyve ağırlığı $\left(\mathrm{kg} \mathrm{adet}^{-1}\right)$ ve meyve yüksekliği (cm) üzerine etkisi. Table 11. The effect of water stress levels on fruit weight $(\mathrm{kg})$ and fruit height $(\mathrm{cm})$ of watermelon. Karpuz meyve ağırlığı (kg adet $\left.{ }^{-1}\right) \quad$ Karpuz meyve yüksekliği (cm)

\begin{tabular}{|c|c|c|c|c|c|c|c|c|c|c|}
\hline Çeşit & $\begin{array}{l}\text { \%100 } \\
\text { Sulama } \\
\text { kontrol }\end{array}$ & $\begin{array}{l}\text { \%50 } \\
\text { Sulama }\end{array}$ & $\begin{array}{l}\text { \%25 } \\
\text { Sulama }\end{array}$ & $\begin{array}{r}\text { Kontrole } \\
\text { göre \%50 } \\
\text { sulamada } \\
\text { değişim } \\
(\%)\end{array}$ & $\begin{array}{r}\text { Kontrole } \\
\text { göre \%25 } \\
\text { sulamada } \\
\text { değişim } \\
(\%)\end{array}$ & $\begin{array}{l}\% 100 \\
\text { Sulama } \\
\text { kontrol }\end{array}$ & $\begin{array}{l}\text { \%50 } \\
\text { Sulama }\end{array}$ & $\begin{array}{l}\text { \%25 } \\
\text { Sulama }\end{array}$ & $\begin{array}{r}\text { Kontrole } \\
\text { göre \%50 } \\
\text { sulamada } \\
\text { değişim } \\
(\%)\end{array}$ & $\begin{array}{r}\text { Kontrole } \\
\text { göre \%25 } \\
\text { sulamada } \\
\text { değişim } \\
(\%)\end{array}$ \\
\hline 52024 & $5.02 \mathrm{a}$ & $5.65 \mathrm{a}$ & $3.34 \mathrm{~b}$ & 12.55 & -33.47 & $25.02 \mathrm{a}$ & $25.12 \mathrm{a}$ & 21.34 & 0.40 & -14.71 \\
\hline Minipool & 3.02 bc & $2.05 \mathrm{c}$ & $2.34 \mathrm{c}$ & -32.12 & -22.52 & $24.09 a$ & $17.45 \mathrm{c}$ & 17.80 & -27.56 & -26.11 \\
\hline Miracle & $4.23 \mathrm{~b}$ & $3.07 \mathrm{~b}$ & $4.23 \mathrm{a}$ & -27.42 & 0.00 & $21.23 \mathrm{~b}$ & $22.98 \mathrm{~b}$ & 21.46 & 8.24 & 1.08 \\
\hline Splendit & $3.45 c$ & $3.98 b$ & $3.24 a b$ & 15.36 & -6.09 & $21.14 \mathrm{~b}$ & $21.13 b$ & 20.21 & -0.05 & -4.40 \\
\hline Starburst & 4.67 bc & $3.32 \mathrm{~b}$ & $4.71 \mathrm{a}$ & -28.91 & 0.86 & $23.18 \mathrm{a}$ & $23.14 \mathrm{a}$ & 20.67 & -0.17 & -10.83 \\
\hline Ortalama & 4.08 & 3.61 & 3.57 & -12.11 & -12.24 & 22.93 & 21.96 & 20.30 & -3.83 & -10.99 \\
\hline $\mathrm{LSD}_{0.05}$ & 0.47 & 0.82 & 0.73 & - & - & 1.64 & 1.68 & Ö.D.* & - & - \\
\hline $\mathrm{P}$ & 0.0036 & 0.0037 & 0.0030 & - & - & 0.0010 & 0.0001 & 0.063 & - & - \\
\hline
\end{tabular}

*Ö.D.: önemli değil.

Karpuz meyve çapı ölçümlerinde beş çeşidin ortalama değerlerine bakıldığında \%50 ve \%25 sulamalarında meyve çapının sırasıyla \%2.27 ve \%7.46 oranında azaldığı kaydedilmiştir. Genel olarak bakıldığında stres arttıkça meyve çapı azalmıştır. Çeşitler arasında Minipool en fazla etkilenme gösterirken en az etkilenme Miracle çeşidinde kaydedilmiştir (Çizelge 12). Said ve Fatiha (2018) beş yöresel ve dört hibrit olmak üzere dokuz karpuz genotipi ile arazide kontrol ve \%50 kısıtlı sulama koşullarında yaptığı denemede, karpuz meyvesi çapı 9 genotip ortalaması olarak kontrolde $19.81 \mathrm{~cm}$ ve \%50 su stresi olan uygulamada ise $17.89 \mathrm{~cm}$ olmuş, kontrole göre karpuz meyve çapı \%9.79 azalmıştır. Karipçin (2009), karpuz genotiplerinde birinci ve ikinci yıl ortalama meyve çapı değerlerini sırasıyla sıfır sulama yapılan parsellerde $12.84-12.79 \mathrm{~cm}$, \%50 sulama yapılan parsellerde $19.48 \mathrm{~cm}-18.38 \mathrm{~cm}$ ve \%100 sulama yapılan kontrol parsellerinde ise $24.08-24.59 \mathrm{~cm}$ olarak belirlemiştir. Kontrol uygulamasına göre birinci ve ikinci yıl denemelerinde sırasıyla sıfır sulanan parsellerde meyve çapı azalması \%47-48 arasında ve \%50 sulanan parsellerde \%19-25 olarak rapor edilmiştir.

Karpuz meyvelerinde genel olarak su stresi seviyesi arttıkça kabuk kalınlığının azaldığı görülmektedir. \%50 ve \%25 sulama uygulamalarında beş çeşidin ortalama meyve kabuk kalınlığı değerleri sırasıyla \%2.26 ve \%7.14 azalma göstermiştir. Meyve kabuk kalınlığı tepkisi bakımından diğer çeşitlerden farklı ve ilginç olarak Splendit çeşidinde ise su stresi \%50'den \%75'e arttıkça meyve kabuğu kalınlığı sırasıyla \%9.91 ve \%15.51 artmıştır. Su stresinin \%75 olduğu uygulamada en fazla kabuk incelmesi gösteren iki çeşit Starburst ve 52024 kodlu çeşit sırasıyla \%12.28 ve \%26.79 olmuştur (Çizelge 12).

Çizelge 12. Su stresi seviyelerinin karpuz meyvesi çapı $(\mathrm{cm})$ ve meyve kabuk kalınlığı $(\mathrm{mm})$ üzerine etkisi. Table 12. The effects of water stress levels on fruit diameter $(\mathrm{cm})$ and thickness of fruit rind $(\mathrm{mm})$ of watermelon.

\begin{tabular}{|c|c|c|c|c|c|c|c|c|c|c|}
\hline \multirow[b]{2}{*}{ Çeşit } & \multicolumn{4}{|c|}{ Karpuz meyve çapı (cm) } & \multicolumn{6}{|c|}{ Karpuz meyve kabuk kalınlığı (mm) } \\
\hline & $\begin{array}{l}\text { \%100 } \\
\text { Sulama } \\
\text { kontrol }\end{array}$ & $\begin{array}{l}\text { \%50 } \\
\text { Sulama }\end{array}$ & $\begin{array}{l}\text { \%25 } \\
\text { Sulama }\end{array}$ & $\begin{array}{r}\text { Kontrole } \\
\text { göre \%50 } \\
\text { sulamada } \\
\text { değişim } \\
(\%)\end{array}$ & $\begin{array}{r}\text { Kontrole } \\
\text { göre \%25 } \\
\text { sulamada } \\
\text { değişim } \\
(\%)\end{array}$ & $\begin{array}{l}\text { \%100 } \\
\text { Sulama } \\
\text { kontrol }\end{array}$ & $\begin{array}{l}\text { \%50 } \\
\text { Sulama }\end{array}$ & $\begin{array}{l}\text { \%25 } \\
\text { Sulama }\end{array}$ & $\begin{array}{r}\text { Kontrole } \\
\text { göre \%50 } \\
\text { sulamada } \\
\text { değişim } \\
(\%)\end{array}$ & $\begin{array}{r}\text { Kontrole } \\
\text { göre \%25 } \\
\text { sulamada } \\
\text { değişim } \\
(\%)\end{array}$ \\
\hline 52024 & 20.45 & $20.56 \mathrm{a}$ & $17.93 \mathrm{a}$ & 0.54 & -12.32 & $14.37 \mathrm{ab}$ & $13.76 \mathrm{ab}$ & $10.52 \mathrm{c}$ & -4.24 & -26.79 \\
\hline Minipool & 18.97 & $16.78 \mathrm{c}$ & $15.14 b$ & -11.54 & -20.19 & $12.59 \mathrm{~b}$ & 12.82 b & $11.98 \mathrm{c}$ & 1.83 & -4.85 \\
\hline Miracle & 19.19 & $18.01 \mathrm{~b}$ & $19.82 \mathrm{a}$ & -6.15 & 3.28 & $15.73 \mathrm{a}$ & $13.69 \mathrm{a}$ & $14.58 \mathrm{~b}$ & -12.97 & -7.31 \\
\hline Splendit & 17.85 & $20.68 a b$ & $17.81 \mathrm{a}$ & 15.85 & -0.22 & $13.02 \mathrm{~b}$ & $14.31 \mathrm{a}$ & $15.04 \mathrm{a}$ & 9.91 & 15.51 \\
\hline Starburst & 20.06 & $18.04 \mathrm{~b}$ & $18.49 a$ & -10.07 & -7.83 & $13.36 \mathrm{ab}$ & $12.58 b$ & 11.72 c & -5.84 & -12.28 \\
\hline Ortalama & 19.30 & 18.81 & 17.84 & -2.27 & -7.46 & 13.81 & 13.43 & 12.77 & -2.26 & -7.14 \\
\hline $\mathrm{LSD}_{0.05}$ & Ö.D.* & 1.29 & 2.00 & - & - & Ö.D.* & 1.12 & 1.13 & - & - \\
\hline$P$ & 0.191 & 0.0007 & 0.021 & - & - & 0.072 & 0.027 & 0.0001 & - & - \\
\hline
\end{tabular}

*Ö.D.: önemli değil.

Said ve Fatiha (2018) beş yöresel ve dört hibrit olmak üzere dokuz karpuz genotipi ile arazide kontrol ve \%50 kısıtlı sulama koşullarında yaptığı denemede, karpuz meyvesi kabuk kalınlığı 9 genotip ortalaması olarak kontrolde 
$16.41 \mathrm{~mm}$ ve \%50 su stresi olan uygulamada ise $12.95 \mathrm{~mm}$ olmuş, kontrole göre karpuz meyvesinde kabuk kalınlığı \%21 azalma göstermiştir. Karipçin (2009)'nin yürüttüğü çalışmada, sıfır sulama yapılan parsellerin ortalama meyve kabuk kalınlığı 15.66 mm-15.30 mm, \%50 sulama yapılan parsellerdeki meyve kabuk kalınlığı 13.40 mm-13.28 mm ve \%100 sulama yapılan kontrol parsellerinde meyve kabuk kalınlığı değerleri $11.60 \mathrm{~mm}-11.58 \mathrm{~mm}$ olarak birinci ve ikinci yıl ortalama kabuk kalınlığı olarak bildirilmiştir. Kontrol uygulamasına göre sıfır sulanan parsellerde kabuk kalınlığı artması iki yıl denemesinde sırasıyla \%35-32 arasında ve \%50 sulanan parsellerde kontrole göre meyve kabuk kalınlığı artışı ise \% 6-17 olarak rapor edilmiştir. Karipçin'in çalışmasında su stresi arttıkça kabuk kalınlığı kontrole göre artmıştır.

\section{Toplam Karpuz Meyve Verimi Üzerine Kuraklık Stresinin Etkileri}

Çalışmada, \%50 ve \%25 sulama uygulamalarında beş çeşit ortalaması olarak kontrole göre sırasıyla \% 12.66 ve \% 11.81 oranında toplam meyve verimi azalması olmuştur. Sulama suyu \%75 azaltılan uygulamada beş çeşidin ortalama verim azalmasının sadece \%11.81 olması önemli ve ilginç bulunmuştur (Çizelge 13). Denemede verim üzerine kuraklık stresinin etkileri çeşit bazında farklı olmuştur. Splendit ve Miracle dışındaki diğer üç çeşitte \%50 ve \%25 sulama koşullarında toplam karpuz verimi azalmıştır. Ancak, Splendit çeşidinde \%50 ve \%25 sulama koşullarında karpuz verimi kontrole göre sırasıyla \%11.07 ve \%26.07 artmıştır. Bu çeşidin su kısıtlamasına uyumunun çok iyi olduğu görülmüştür. Miracle çeşidinin \%50 sulamada toplam verimi \%4.10 azaltırken, \%25 sulama koşullarında ise \%5.11 artırdığı görülmüştür. Miracle çeşidi Splendit kadar olmasa da su stresine adaptasyonu diğer üç karpuz çeşidine göre daha toleranslı bulunmuştur. 52024 numaralı çeşit $5454 \mathrm{~kg} \mathrm{da}^{-1}$ ile denemede kontrol koşullarında en yüksek verimli çeşit olarak belirlenmiştir. Bu çeşidin \%50 sulama koşullarında verim azalması \%17.88 civarında $4480 \mathrm{~kg} \mathrm{da}^{-1}$ olarak belirlenmiştir. Yüksek verimi nedeniyle 52024 çeşit, suyun \%50 az olduğu koşullarda önerilebilir bulunmuştur. Ancak \%25 sulamada \%50.61 ani bir verim düşmesi gerçekleşmiştir (Çizelge 13). Starburst çeşidi \%50 ve \%25 sulama koşullarında karpuz veriminde sırasıyla \%16.98 ve \%1 verim azalması göstermiştir. Starburst çeşidi \%25 sulama uygulamasında çok az bir verim azalması ile önerilebilir çeşitler arasına girmiştir. Minipool çeşidi \%50 ve \%25 sulama koşullarında karpuz veriminde sırasıyla \%35.49 ve \%38.69 verim azalması göstermiştir. Karipçin (2009)'nin karpuz genotiplerinde yürüttüğü çalışmada,

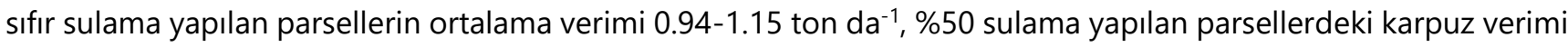
3.93-3.94 ton $\mathrm{da}^{-1}$ ve $\% 100$ sulama yapılan kontrol parsellerinde verim değerleri 8.77-7.73 ton da $\mathrm{da}^{-1}$ olarak birinci ve ikinci yıl verimi şeklinde bildirilmiştir. Kontrol uygulamasına göre sıfır sulanan parsellerde verim azalması iki yıl denemesinde sırasıyla \%85-89 arasında ve \%50 sulanan parsellerde kontrole göre verim azalması \% 55-49 olarak rapor edilmiştir.

Çizelge 13. Su stresi seviyelerinin karpuz bitkisinin toplam meyve verimi $\left(\mathrm{kg} \mathrm{da}^{-1}\right)$ ve meyvede toplam kuru madde üretim miktarı (\%) üzerine etkisi.

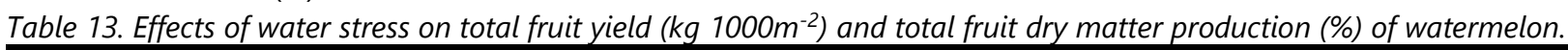

\begin{tabular}{|c|c|c|c|c|c|c|c|c|c|c|}
\hline \multirow[b]{2}{*}{ Çeşit } & \multicolumn{5}{|c|}{ Toplam meyve verimi $\left(\mathrm{kg} \mathrm{da}^{-1}\right)$} & \multicolumn{5}{|c|}{ Meyvede toplam kuru madde miktarı (\%) } \\
\hline & $\begin{array}{l}\text { \%100 } \\
\text { Sulama } \\
\text { kontrol }\end{array}$ & $\begin{array}{l}\text { \%50 } \\
\text { Sulama }\end{array}$ & $\begin{array}{r}\% 25 \\
\text { Sulama }\end{array}$ & $\begin{array}{r}\text { Kontrole } \\
\text { göre \%50 } \\
\text { sulamada } \\
\text { değişim } \\
(\%)\end{array}$ & $\begin{array}{r}\text { Kontrole } \\
\text { göre \%25 } \\
\text { sulamada } \\
\text { değişim } \\
(\%)\end{array}$ & $\begin{array}{r}\% 100 \\
\text { Sulama } \\
\text { kontrol }\end{array}$ & $\begin{array}{r}\% 50 \\
\text { Sulama }\end{array}$ & $\begin{array}{r}\% 25 \\
\text { Sulama }\end{array}$ & $\begin{array}{r}\text { Kontrole } \\
\text { göre \%50 } \\
\text { sulamada } \\
\text { değişim } \\
(\%)\end{array}$ & $\begin{array}{r}\text { Kontrole } \\
\text { göre \%25 } \\
\text { sulamada } \\
\text { değişim } \\
(\%)\end{array}$ \\
\hline 52024 & 5454 a & 4480 a & $2695 \mathrm{~b}$ & -17.88 & -50.61 & $9.10 \mathrm{c}$ & 9.05 & 9.07 & -0.55 & -0.33 \\
\hline Minipool & $3308 \mathrm{~b}$ & $2135 d$ & 2029 c & -35.49 & -38.69 & $10.05 \mathrm{ab}$ & 9.55 & 9.22 & -4.98 & -8.26 \\
\hline Miracle & $3679 b$ & $3529 b$ & 3867 a & -4.10 & 5.11 & $8.99 \mathrm{c}$ & 9.23 & 9.24 & 2.67 & 2.78 \\
\hline Splendit & $2700 c$ & 2999 bc & 3405 a & 11.07 & 26.07 & $9.38 \mathrm{bc}$ & 9.57 & 9.94 & 2.03 & 5.97 \\
\hline Starburst & $3499 \mathrm{~b}$ & $2905 c$ & 3464 a & -16.98 & -1.00 & $10.79 a$ & 10.60 & 10.23 & -1.76 & -5.19 \\
\hline Ortalama & 3728 & 3209.6 & 3092 & -12.66 & -11.81 & 9.66 & 9.60 & 9.54 & -0.52 & -1.01 \\
\hline $\mathrm{LSD}_{0.05}$ & 535.159 & 533.738 & 558.198 & - & - & 0.92 & Ö.D.* & Ö.D.* & - & - \\
\hline P & $<0.0001$ & $<0.0001$ & 0.0005 & - & - & 0.0136 & 0.671 & 0.211 & - & - \\
\hline
\end{tabular}

*Ö.D.: önemli değil.

Karpuz meyvelerinde toplam kuru madde miktarı \%50 ve \%25 sulama uygulamalarında beş çeşit ortalaması olarak kontrole göre sırasıyla \%0.52 ve 1.01 oranlarında azalma göstermiştir (Çizelge 13). Çeşit bazında meyvede toplam kuru madde azalması en fazla Minipool ve sonra Starbust çeşitlerinde olurken, Splendit ve Miracle çeşitlerinde ise kuru madde artmıştır. Splendit çeşidinde \%2.03-5.97 arasında ve Miracle çeşidinde ise \%2.67-2.78 
civarında artışlar kaydedilmiştir. 52024 numaralı çeşidin ise stres koşullarında kontrol gibi kararlı olduğu ve meyvede toplam kuru madde miktarı pek de etkilenmediği söylenebilir.

Karpuz meyvelerinde sayı olarak tohum miktarı \%50 sulamada beş çeşidin ortalaması olarak \%5.27 azalma gösterirken, su stresinin arttığı \%25 sulamada \%4.65 artmıştır. Çeşit bazında tepkiler oldukça farklıık göstermektedir. Minipool çeşidinde her iki su stresi uygulamasında \%46.79-56.88 arasında tohum sayısı azalırken. Splendit çeşidinde ise her iki su stresi uygulamasında \%50 civarında tohum sayısı artırılmıştır. Splendit çeşidinin su stresine tepki olarak neslini devam ettirmek gayreti ile bitkilerin döllenen tohum sayısını kontrole göre epey bir artırma eğilimine girdiği görülmektedir (Çizelge 14). Karipçin (2009)'nin karpuz genotiplerinde yürüttüğü çalışmada, sıfır sulama yapılan parsellerin ortalama tohum sayısı 327-362 adet meyve ${ }^{-1}, \% 50$ sulama yapılan parsellerdeki tohum sayısı 441-471 adet meyve ${ }^{-1}$ ve $\% 100$ sulama yapılan kontrol parsellerinde tohum sayısı 417458 adet meyve ${ }^{-1}$ olarak sırasıyla birinci ve ikinci yıl ortalama tohum sayısı olarak bildirilmiştir. Kontrol uygulamasına göre sıfır sulanan parsellerde tohum sayısı iki yıl denemesinde sırasıyla \%22-21 arasında azalma gösterirken, \%50 sulanan parsellerde kontrole göre tohum sayısı ise \%5.7-2.8 oranında artış olarak rapor edilmiştir.

Karpuz meyvelerinde tohum miktarının ağırlık olarak etkilenmesine bakıldığında beş çeşidin ortalaması olarak \%50 sulamada kontrole göre çok az bir azalma \%0.98 olurken, \%25 sulamada \%14.94 artış kaydedilmiştir (Çizelge 14). Çeşitler bazında Minipool \%35-41 arasında kontrole göre tohum ağılık kaybı en fazla olan çeşit iken, Splendit \%54-89 arasında tohum ağırlığı en fazla artış gösteren çeşit olmuştur. Splendit çeşidinin neslin devamını sağlamak üzere strese tepkisel olarak, sayısını ve tohum ağırlığını artırması meyve kalitesi bakımından bir dezavantaj görülebilir. Ancak bu çeşidin kontrol uygulamasındaki meyve başına tohum sayısı ve ağırı̆̆ına bakıldığında diğerlerine göre en az tohum görülmektedir.

Çizelge 14. Su stresi seviyelerinin karpuz bitkisinde meyve başına tohum sayısı (adet meyve-1) ve meyve başına ağırlık olarak tohum miktarı $\left(\mathrm{g}\right.$ meyve $\left.{ }^{-1}\right)$ üzerine etkisi.

Table 14. The effects of water stress levels on the number of seeds per fruit (seed fruit ${ }^{-1}$ ) and the amount of seeds per fruit weight $\left(\mathrm{g}\right.$ fruit $\left.^{-1}\right)$ of the watermelon.

\begin{tabular}{|c|c|c|c|c|c|c|c|c|c|c|}
\hline \multirow[b]{2}{*}{ Çeşit } & \multicolumn{5}{|c|}{ Meyve başına tohum sayısı (adet meyve ${ }^{-1}$ ) } & \multicolumn{5}{|c|}{ Meyve başına tohum ağırlığı (g meyve ${ }^{-1}$ ) } \\
\hline & $\begin{array}{l}\% 100 \\
\text { Sulama } \\
\text { kontrol }\end{array}$ & $\begin{array}{l}\% 50 \\
\text { Sulama }\end{array}$ & $\begin{array}{l}\% 25 \\
\text { Sulama }\end{array}$ & $\begin{array}{r}\text { Kontrole } \\
\text { göre \%50 } \\
\text { sulamada } \\
\text { değişim } \\
(\%)\end{array}$ & $\begin{array}{r}\text { Kontrole } \\
\text { göre \%25 } \\
\text { sulamada } \\
\text { değişim } \\
(\%)\end{array}$ & $\begin{array}{l}\% 100 \\
\text { Sulama } \\
\text { kontrol }\end{array}$ & $\begin{array}{l}\text { \%50 } \\
\text { Sulama }\end{array}$ & $\begin{array}{l}\% 25 \\
\text { Sulama }\end{array}$ & $\begin{array}{r}\text { Kontrole } \\
\text { göre \%50 } \\
\text { sulamada } \\
\text { değişim } \\
(\%)\end{array}$ & $\begin{array}{r}\text { Kontrole } \\
\text { göre \%25 } \\
\text { sulamada } \\
\text { değişim } \\
(\%)\end{array}$ \\
\hline 52024 & $145 \mathrm{~b}$ & $119 \mathrm{~d}$ & $149 \mathrm{bc}$ & -17.93 & 2.76 & $8.50 \mathrm{c}$ & $7.17 \mathrm{c}$ & $7.80 \mathrm{c}$ & -15.65 & -8.24 \\
\hline Minipool & $218 \mathrm{a}$ & $94 \mathrm{e}$ & $116 \mathrm{c}$ & -56.88 & -46.79 & $6.31 \mathrm{~d}$ & $3.71 \mathrm{~d}$ & $4.08 \mathrm{~d}$ & -41.20 & -35.34 \\
\hline Miracle & 192 a & 216 a & $182 \mathrm{~b}$ & 12.50 & -5.21 & $9.13 \mathrm{~b}$ & $10.98 \mathrm{a}$ & $9.11 \mathrm{~b}$ & 20.26 & -0.22 \\
\hline Splendit & $102 \mathrm{c}$ & $153 \mathrm{c}$ & $154 \mathrm{bc}$ & 50.00 & 50.98 & $4.48 \mathrm{e}$ & $6.89 c$ & $8.46 b$ & 53.79 & 88.84 \\
\hline Starburst & $214 a$ & $184 \mathrm{~b}$ & $260 \mathrm{a}$ & -14.02 & 21.50 & $11.84 a$ & 9.22 b & $15.35 \mathrm{a}$ & -22.13 & 29.65 \\
\hline Ortalama & 174 & 153 & 172 & -5.27 & 4.65 & 8.05 & 7.59 & 8.96 & -0.98 & 14.94 \\
\hline $\mathrm{LSD}_{0.05}$ & 29.08 & 13.32 & 43.86 & - & - & 1.08 & 1.47 & 1.54 & - & - \\
\hline$P$ & 0.0001 & 0.0001 & 0.0007 & - & - & 0.0001 & 0.0001 & 0.0001 & - & - \\
\hline
\end{tabular}

Karpuz meyvesi içerisinden kırmızı et kısmında Hunter renk ölçüm cihazı kullanılarak ölçülen renk paramtrelerinden $L$ parlaklığı ifade etmektedir. Karpuz meyvesi iç rengi parlaklık durumu, beş çeşit ortalamasına göre genel olarak 50 sulamada etkilenmiştir ve \% 0.84 artma olmuştur, ancak \%25 sulamada \%4.12'lik bir azalma kaydedilmiştir. Çeşitler bazında Splendit hariç diğer dört çeşit \%50 sulamada meyve eti parlaklığında \%2.69-5.74 arasında artış göstermiştir. Splendit ise \%9.47 parlaklıkta azalma göstermiştir. \% 25 sulama uygulamasında ise çeşitler \%1.52 ile \%11.66 arasında L değerinde azalma göstermiştir (Çizelge 15).

Su stresi uygulamalarından \%50 sulamada beş çeşidin ortalaması olarak a değerinde, \%2.32 oranında bir kırmızı renk azalmasına neden olurken, \%25 sulamada ise \%1.03'lük bir artma oluşturmuştur (Çizelge 15). Çeşit bazında a değerlerine bakıldığında \%50 sulamada Miracle çeşidinde \%3.75 artış görülürken, Splendit çeşidinde ise \%7.83'lük bir azalma belirlenmiştir. \%25 sulama uygulamasında en fazla kırmızı renk artışı \%3.70 ile 52024 kod numaralı çeşitte ve sonra \%4.88 bir artış da Miracle çeşidinde kaydedilmiştir. 
Çizelge 15. Su stresi seviyelerinin karpuz meyvesi iç rengi Hunter cihazı okuması L değeri, parlaklık ve meyve iç rengi Hunter cihazı okuması a değeri üzerine etkisi.

Table 15. The effect of water stress levels on the fruit inner color Hunter device reading $L$ value, brightness and fruit core color Hunter device reading a value of the watermelon.

\begin{tabular}{|c|c|c|c|c|c|c|c|c|c|c|}
\hline \multirow[b]{2}{*}{ Çeşit } & \multicolumn{5}{|c|}{ Meyve iç rengi Hunter cihazı L değeri, parlaklık } & \multicolumn{4}{|c|}{ Meyve iç rengi Hunter cihazı a değeri } & \multirow[b]{2}{*}{$\begin{array}{r}\text { Kontrole } \\
\text { göre \%25 } \\
\text { sulamada } \\
\text { değişim } \\
(\%)\end{array}$} \\
\hline & $\begin{array}{l}\text { \%100 } \\
\text { Sulama } \\
\text { kontrol }\end{array}$ & $\begin{array}{l}\% 50 \\
\text { Sulama }\end{array}$ & $\begin{array}{l}\% 25 \\
\text { Sulama }\end{array}$ & $\begin{array}{r}\text { Kontrole } \\
\text { göre \%50 } \\
\text { sulamada } \\
\text { değişim } \\
(\%)\end{array}$ & $\begin{array}{r}\text { Kontrole } \\
\text { göre \%25 } \\
\text { sulamada } \\
\text { değişim } \\
(\%)\end{array}$ & $\begin{array}{l}\% 100 \\
\text { Sulama } \\
\text { kontrol }\end{array}$ & $\begin{array}{l}\% 50 \\
\text { Sulama }\end{array}$ & $\begin{array}{l}\text { \%25 } \\
\text { Sulama }\end{array}$ & $\begin{array}{r}\text { Kontrole } \\
\text { göre \%50 } \\
\text { sulamada } \\
\text { değişim } \\
(\%)\end{array}$ & \\
\hline 52024 & $39.4 \mathrm{c}$ & 40.4 bc & $34.8 \mathrm{c}$ & 2.69 & -11.66 & $36.8 \mathrm{c}$ & $35.7 \mathrm{~b}$ & $38.1 \mathrm{~b}$ & -2.77 & 3.70 \\
\hline Minipool & $39.7 c$ & $41.9 \mathrm{~b}$ & $40.1 \mathrm{ab}$ & 5.74 & 0.96 & $37.3 \mathrm{bc}$ & $36.1 \mathrm{~b}$ & $36.5 c$ & -3.22 & -2.20 \\
\hline Miracle & $40.5 \mathrm{bc}$ & $41.5 \mathrm{~b}$ & $39.7 \mathrm{~b}$ & 2.35 & -2.05 & $37.1 \mathrm{~b}$ & 38.5 a & $38.9 \mathrm{~b}$ & 3.75 & 4.88 \\
\hline Splendit & $44.2 \mathrm{a}$ & $39.9 c$ & $41.4 \mathrm{ab}$ & -9.47 & -6.32 & 39.5 a & $36.4 \mathrm{ab}$ & $39.1 \mathrm{a}$ & -7.83 & -0.94 \\
\hline Starburst & $42.7 \mathrm{ab}$ & $43.9 \mathrm{a}$ & $42.0 \mathrm{a}$ & 2.91 & -1.52 & 37.1 bc & $36.5 \mathrm{~b}$ & $36.9 c$ & -1.54 & -0.30 \\
\hline Ortalama & 41.3 & 41.5 & 39.6 & 0.84 & -4.12 & 37.5 & 36.6 & 37.9 & -2.32 & 1.03 \\
\hline $\mathrm{LSD}_{0.05}$ & 2.10 & 1.51 & 2.47 & - & - & 1.13 & 1.32 & 1.07 & - & - \\
\hline $\mathrm{P}$ & 0.0028 & 0.0108 & 0.0008 & - & - & 0.0068 & 0.0157 & 0.0005 & - & - \\
\hline
\end{tabular}

Genel olarak beş çeşidin ortalamasına göre b renk değeri \%50 ve \%25 sulama uygulamalarında sırası ile \%2.58 ile \%4.88 oranında artış göstermiş̧ir. Splendit çeşidinde su stresi arttıkça b değeri artmamış aynı kalmıştır (Çizelge 16).

Çalışmada meyvelerin EC değeri \%50 ve \%25 sulamalarda sırasıyla \%5.10 ve \%6.84 düzeylerinde azalma göstermiştir. Sulama suyunun azaltılması meyveye mineral taşınmasını azaltmışırı. Çeşitler bazında karpuz meyvesi EC azalması 52024 nolu çeşitte \%10.90-14.01 arasında ve Starburst çeşidinde \%12.06-12.88 arasında gözlenirken, diğer çeşitlerde ise \%0.67-7.21 arasında kalmıştır. Spendit çeşidinde ise EC artmıştır. (Çizelge 16).

Çizelge 16. Su stresi seviyelerinin karpuz meyvesi iç rengi Hunter cihazı okuması b değeri ve meyvede EC değeri üzerine etkisi. Table 16. Effect of water stress levels on fruit inner color of watermelon Hunter device reading $b$ value and fruit EC value. Meyve iç rengi Hunter cihazı b değeri Karpuz meyvesi EC değeri $\left(\mu \mathrm{S} \mathrm{cm}^{-1}\right)$

\begin{tabular}{|c|c|c|c|c|c|c|c|c|c|c|}
\hline Çeşit & $\begin{array}{l}\text { \%100 } \\
\text { Sulama } \\
\text { kontrol }\end{array}$ & $\begin{array}{l}\text { \%50 } \\
\text { Sulama }\end{array}$ & $\begin{array}{l}\text { \%25 } \\
\text { Sulama }\end{array}$ & $\begin{array}{r}\text { Kontrole } \\
\text { göre \%50 } \\
\text { sulamada } \\
\text { değişim } \\
(\%)\end{array}$ & $\begin{array}{r}\text { Kontrole } \\
\text { göre \%25 } \\
\text { sulamada } \\
\text { değişim } \\
(\%)\end{array}$ & $\begin{array}{l}\text { \%100 } \\
\text { Sulama } \\
\text { kontrol }\end{array}$ & $\begin{array}{l}\text { \%50 } \\
\text { Sulama }\end{array}$ & $\begin{array}{l}\text { \%25 } \\
\text { Sulama }\end{array}$ & $\begin{array}{l}\text { Kontrole } \\
\text { göre \%50 } \\
\text { sulamada } \\
\text { değişim } \\
(\%)\end{array}$ & $\begin{array}{l}\text { Kontrole } \\
\text { göre \%25 } \\
\text { sulamada } \\
\text { değişim } \\
\text { (\%) }\end{array}$ \\
\hline 52024 & $22.1 \mathrm{a}$ & $21.2 \mathrm{c}$ & $23.6 \mathrm{~b}$ & -4.20 & 6.83 & $655 a$ & $584 \mathrm{~b}$ & $564 \mathrm{~b}$ & -10.90 & -14.01 \\
\hline Minipool & 22.8 a & $23.6 \mathrm{ab}$ & $24.1 \mathrm{a}$ & 3.60 & 5.98 & $558 c$ & $554 \mathrm{c}$ & $518 d$ & -0.67 & -7.21 \\
\hline Miracle & $21.6 b$ & $24.1 \mathrm{a}$ & $21.9 c$ & 11.55 & 1.86 & $560 \mathrm{c}$ & $534 \mathrm{~cd}$ & $555 \mathrm{bc}$ & -4.55 & -0.92 \\
\hline Splendit & $21.1 b c$ & $22.5 b$ & $22.5 b$ & 6.74 & 6.74 & $599 \mathrm{~b}$ & 619 a & 599 a & 3.47 & 0.02 \\
\hline Starburst & $20.4 c$ & $19.5 \mathrm{~d}$ & $21.0 \mathrm{c}$ & -4.80 & 2.99 & $606 b$ & $528 d$ & $533 \mathrm{~cd}$ & -12.88 & -12.06 \\
\hline Ortalama & 21.59 & 22.15 & 22.7 & 2.58 & 4.88 & 596 & 564 & 554 & -5.10 & -6.84 \\
\hline $\mathrm{LSD}_{0.05}$ & 1.18 & 0.97 & 0.77 & - & - & 22.54 & 26.21 & 25.00 & - & - \\
\hline$P$ & 0.0040 & 0.001 & 0.0002 & - & - & 0.0001 & 0.0002 & 0.0007 & - & - \\
\hline
\end{tabular}

Karpuz bitkisi su kısıtlaması ile yetiştirildiğinde meyve $\mathrm{pH}$ değerlerinde kontrole göre düşmeler kaydedilmiştir. Beş çeşidin ortalaması olarak \%50 sulamada \%10.81 ve \%25 sulamada ise \%17.27 pH düşmesi kaydedilmiştir. Su stresinin artması karpuz meyvelerini genel olarak daha asidik yapmıştır. Çeşit bazında Miracle çeşidinde 16.7720.73 arasında $\mathrm{pH}$ düşmesi kaydedilirken, Starburst çeşidinde her iki sulamada da \%9.84 sabit bir pH düşmesi kaydedilmiştir (Çizelge 17).

Su stresi karpuz meyvelerinde SÇKM'nin düşmesine neden olmuştur. Beş çeşit ortalaması olarak \%50 ve \%25 sulanan bitkilerde meyve SÇKM değerleri sırasıyla \%9.32 ve \%16.05 azalmıştır. Su stresi arttıkça SÇKM daha çok azalmıştır. Çeşit bazında en fazla azalma Miracle çeşidinde \%21.16-27.09 arasında görülmüştür. Splendit çeşidinde \%13.59-16.04 arasında ve Starburst çeşidinde ise \%4.08-5.44 SÇKM azalması kaydedilmiştir (Çizelge 17). Said ve Fatiha (2018) beş yöresel ve dört hibrit olmak üzere dokuz karpuz genotipi ile arazide kontrol ve \%50 kısıtlı sulama koşullarında yaptığı denemede, karpuz meyvesi SÇKM içeriği 9 genotip ortalaması olarak kontrolde \%8.42 ve \%50 su stresi olan uygulamada ise \%7.34 olmuş, kontrole göre SÇKM \%12.8 azalmıştır. Karipçin (2009)'nin karpuz 
genotiplerinde yürüttüğü çalışmada, sıfır sulama yapılan parsellerin ortalama SÇKM'si \%7.5-7.4, \%50 sulama yapılan parsellerdeki SÇKM değerleri \%8.2-\%8.0 ve \%100 sulama yapılan kontrol parsellerinde SÇKM değerleri \%8.30-8.25 olarak, birinci ve ikinci yıl ortalama SÇKM olarak bildirilmiştir. Kontrol uygulamasına göre sıfır sulanan parsellerde SÇKM azalması \%9.6-10.06 ve \%50 sulanan parsellerde SÇKM azalısı ise \%1.2-3.6 olarak rapor edilmiştir.

Çizelge 17. Su stresi seviyelerinin karpuz meyvesi pH ve SÇKM değerleri üzerine etkisi. Table 17. The effect of water stress levels on fruit $\mathrm{pH}$ and fruit brix (total soluble solids) of watermelon.

\begin{tabular}{|c|c|c|c|c|c|c|c|c|c|c|}
\hline \multirow[b]{2}{*}{ Çeşit } & \multicolumn{4}{|c|}{ Karpuz meyvesi pH } & \multirow[b]{2}{*}{$\begin{array}{r}\text { Kontrole } \\
\text { göre \%25 } \\
\text { sulamada } \\
\text { değişim } \\
(\%)\end{array}$} & \multicolumn{5}{|c|}{ Karpuz meyvesi SÇKM (\%) } \\
\hline & $\begin{array}{l}\text { \%100 } \\
\text { Sulama } \\
\text { kontrol }\end{array}$ & $\begin{array}{l}\text { \%50 } \\
\text { Sulama }\end{array}$ & $\begin{array}{l}\% 25 \\
\text { Sulama }\end{array}$ & $\begin{array}{r}\text { Kontrole } \\
\text { göre \%50 } \\
\text { sulamada } \\
\text { değişim } \\
(\%)\end{array}$ & & $\begin{array}{l}\text { \%100 } \\
\text { Sulama } \\
\text { kontrol }\end{array}$ & $\begin{array}{l}\% 50 \\
\text { Sulama }\end{array}$ & $\begin{array}{l}\% 25 \\
\text { Sulama }\end{array}$ & $\begin{array}{r}\text { Kontrole } \\
\text { göre \%50 } \\
\text { sulamada } \\
\text { değişim } \\
(\%)\end{array}$ & $\begin{array}{r}\text { Kontrole } \\
\text { göre \%25 } \\
\text { sulamada } \\
\text { değişim } \\
(\%)\end{array}$ \\
\hline 52024 & $6.67 \mathrm{a}$ & $5.21 \mathrm{~b}$ & $5.45 \mathrm{c}$ & -21.89 & -18.29 & $8.32 \mathrm{~b}$ & $7.34 \mathrm{bc}$ & $6.54 \mathrm{bc}$ & -11.78 & -21.39 \\
\hline Minipool & $6.76 \mathrm{~b}$ & $6.64 \mathrm{ab}$ & $5.54 \mathrm{c}$ & -1.78 & -18.05 & $7.78 \mathrm{~b}$ & $8.09 \mathrm{a}$ & $6.98 a b$ & 3.98 & -10.28 \\
\hline Miracle & $6.56 \mathrm{~b}$ & $5.46 \mathrm{c}$ & $5.20 \mathrm{a}$ & -16.77 & -20.73 & $9.45 \mathrm{a}$ & $7.45 \mathrm{~b}$ & $6.89 c$ & -21.16 & -27.09 \\
\hline Splendit & $6.32 b$ & $6.08 a$ & $5.09 a b$ & -3.80 & -19.46 & $8.98 \mathrm{a}$ & $7.76 \mathrm{c}$ & $7.54 \mathrm{a}$ & -13.59 & -16.04 \\
\hline Starburst & $5.69 \mathrm{c}$ & $5.13 \mathrm{c}$ & $5.13 \mathrm{bc}$ & -9.84 & -9.84 & $8.09 a$ & $7.76 \mathrm{bc}$ & $7.65 \mathrm{ab}$ & -4.08 & -5.44 \\
\hline Ortalama & 6.40 & 5.70 & 5.28 & -10.81 & -17.27 & 8.52 & 7.68 & 7.12 & -9.32 & -16.05 \\
\hline $\mathrm{LSD}_{0.05}$ & 0.14 & 0.11 & 0.22 & - & - & 0.40 & 0.36 & 0.57 & - & - \\
\hline $\mathrm{P}$ & 0.0001 & 0.0001 & 0.0069 & - & - & 0.003 & 0.0019 & 0.0104 & - & - \\
\hline
\end{tabular}

\section{SONUÇ}

Bu çalışmada, Çukurova bölgesi ekolojik koşullarında yaz aylarında arazi koşullarında karpuz bitkisinin su kısıtlaması ile kuraklık stresi altında yetiştirilmesi sonucunda agronomik, fizyolojik ve pomolojik özellikler incelenerek, \%75 su kısıtlamasına kadar olan stres koşullarında başarılı bulunan çeşitler Splendit ve Miracle olmuştur. Özel durumlarda suyun \%50 kısıtı aşmaması halinde Starburst ve 50024 numaralı çeşitler de tercih edilebilir bulunmuştur.

İklim değişikliğinin tarımsal üretimi etkilemeye başlaması ile kuraklık stresine toleranslı ve az su ile ekonomik olarak yeterlilik düzeyinde başarılı yetiştirilebilen çeşitler yakın gelecekte önem kazanacaktır. Kuraklık stresine toleranslı çeşitlerin ortaya çıkarılarak üreticilere önerilmesi ve sonraki aşamada yeni kurak tolerant çeşitlerin geliştirilmesi büyük önem arz etmektedir.

\section{ÇIKAR ÇATIŞMASI}

Yazarlar herhangi bir çıkar çatışması olmadığını beyan eder.

\section{YAZAR KATKISI}

Prof. Dr. H. Yıldız Daşgan araştırmanın planlanması, yürütülmesi, sonuçların değerlendirilmesi, verilerin istatistik yapılması ve makale yazımında, Ziraat Yük. Müh. Musa Kılıç çalışmanın arazide yürütülmesinde, ölçüm ve analizlerde, verilerin elde edilmesinde ve istatistik yapılmasında, araştırııılar Dr. Sultan Dere ve Ar. Gör. Boran İkiz bitki ölçümlerinde ve laboratuvarda yapılan analizlerde, makale yazılmasında çalışmaya katkı sunmuşlardır.

\section{TEŞEKKÜR}

Bu çalışma, Çukurova Üniversitesi Rektörlüğü Bilimsel Araştırma Projeleri Koordinasyon Birimi tarafından finansal olarak FYL-2019-11493 nolu Yüksek Lisans tez projesi ile desteklenmiştir. Yazarlar finansal destek için teşekkür etmektedir.

\section{KAYNAKLAR}

Akhoundnejad, Y., \& Daşgan, H. Y. (2019). Effect of different irrigation levels on physiological performance of some drought tolerant melon (Cucumis melo L.) genotypes. Applied Ecology and Environmental Research, 17(4), 9997-10012. 
Anonim, (2021a). Food and Agriculture Organization (FAO), Gıda ve Tarım Organizasyonu, http://www.fao.org/faostat/en/\#data/QC. Erişim tarihi: 24 Mayıs 2021.

Anonim, (2021b). Bitkisel üretim istatistikleri (TÜiK), https://data.tuik.gov.tr/Kategori/GetKategori?p=tarim-111\&dil=1. Erişim tarihi: 28 Mayıs 2021.

Carroll, D. A., Hansen, N. C., Hopkins, B. G., \& DeJonge, K. C. (2017). Leaf temperature of maize and crop water stress Index with variable irrigation and nitrogen supply. Irrigation Science, 35, 549-560.

Daşgan, H. Y., \& Akhoundnejad, Y. (2014). Türkiye F1 hibrit çeşit ve niteliki hat geliştirilmesi. 1007-TÜBiTAK-KAMAG Projesi "Kavunda Kuraklığa Tolerant Nitelikli Hat ve Çeşit Geliştirilmesi" Alt Projesi (109G099) Sonuç Raporu.

Dere, S. (2019). Domateste besin özellikleri ve kalitenin kuraklığa dayanıklılıla arttırılması. Doktora Tezi, Çukurova Üniversitesi, Fen Bilimleri Enstitüsü, Adana.

Dlugokecka, E., \& Kacperska-Palacz, A. (1978). Re-examination of electrical conductivity method for estimation of drought injury. Biologia Plantarum, 20, 262-267.

Fan, S., \& Blake, T. G. (1994). Abscisic acid induced electrolyte leakage in woody species with contrasting ecological requirements. Plant Physiology, 89, 817-823.

Gould, W. A. (1977). Food Quality Assurance. AVI Publishing Co: Westport CT.

Jones, H. G., \& Corlett, J. E. (1992). Current topics in drought physiology. Journal of Agricultural Science, 119, $291-296$.

JUMP. 2007. Version 7.0, Statistical Software.

Kapluhan, E., 2013. Türkiye'de kuraklık ve kuraklığın tarıma etkisi. Marmara Coğrafya Dergisi, 27, 487-510.

Karipçin, M. Z. (2009). Yerli ve yabani karpuz genotiplerinde kuraklığa toleransın belirlenmesi. Doktora Tezi, Çukurova Üniversitesi, Fen Bilimleri Enstitüsü, Adana.

Kıran, S., Kuşvuran, Ş., Ateş, Ç., \& Ellialtıoğlu, Ş. Ş. (2018). Tuzluluk ve su noksanlığı stresi altında yetiştirilen farklı patlıcan anaç/kalem kombinasyonlarında bazı meyve kalite özelliklerine ait değişimler. Derim, 35(2), 111-120.

Kozlowski, T. T., \& Pallardy, S. G. (1997). Physiology of Woody Plants, Academic Press, San Diego.

Mo, Y. L., Zheng, J. X., Yang, R. P., Liu, C. M., Gu, X. R., Zhang, X., \& Wei, C. H. (2016a). Physiological responses and tolerance to drought stress of different watermelon genotypes. The Journal of Applied Ecology, 27(6), 1942-1952.

Mo, Y., Yang, R., Liu, L., Gu, X., Yang, X., Wang, Y., Zhang, X., \& Li, H. (2016b). Growth, photosynthesis and adaptive responses of wild and domesticated watermelon genotypes to drought stress and subsequent re-watering. Plant Growth Regulation, 79, 229-241.

Öktem, A. U., \& Aksoy, A. (2014). Türkiye'nin Su Riskleri Raporu. Ofset Yapımevi, İstanbul.

Said, E. M., \& Fatiha, H. (2018). Genotypic variability in fruits characters of moroccan watermelon cultivars (Citrullus Lanatus) cultivars under well and limited watered conditions. Horticulture International Journal, 2(6), 378-381.

Sánchez, F. J., Andres, E. F., Tenorio, J. L., \& Ayerbe, L. (2004). Growth of epicotyls, turgor maintenance and osmotic adjustment in pea plants (Pisum sativum L.) subjected to water stress, Field Crops Research, 86(1), 81-90.

Silva, E. N., Ribeiro, R. V., Ferreira-Silva, S. L., Viégas, R. A., \& Silveira, J. A. G. (2010). Comparative effects of salinity and water stress on photosynthesis, water relations and growth of Jatropha curcas plants. Journal of Arid Environments, 74(10), 11301137.

Türkan, İ., Bor, M., Özdemir, F., \& Koca, H. (2005). Differantial Responses of Lipid peroxidation and antioxidants in the leaves of drought-tolerant P. acutifolius Gray and drought-sensitive P. vulgaris L. subjected to polyethylene glycol mediated water stress. Plant Science, 168(1), 223-231.

Yokota, A., Kawasaki, S., Iwano, M., Nakamura, C., Miyake, C., \& Akashi, K. (2002). Citrulline and DRIP-1 protein in drought tolerance of wild watermelon. Annals of Botany, 89(7), 825-832. 